\title{
Bringing Transition Management to Cities: Building Skills for Transformative Urban Governance
}

\author{
Niki Frantzeskaki ${ }^{1,2}$
}

Citation: Frantzeskaki, N. Bringing Transition Management to Cities: Building Skills for Transformative Urban Governance. Sustainability 2022, 14, 650. https://doi.org/ $10.3390 /$ su14020650

Academic Editor: Jan K. Kazak

Received: 22 August 2021

Accepted: 5 January 2022

Published: 7 January 2022

Publisher's Note: MDPI stays neutral with regard to jurisdictional claims in published maps and institutional affiliations.

Copyright: (C) 2022 by the author. Licensee MDPI, Basel, Switzerland. This article is an open access article distributed under the terms and conditions of the Creative Commons Attribution (CC BY) license (https:/ / creativecommons.org/licenses/by/ $4.0 /)$.
1 Centre for Urban Transitions, Swinburne University of Technology, Melbourne, VIC 3101, Australia; nfrantzeskaki@swin.edu.au

2 Dutch Research Institute for Transitions (DRIFT), Erasmus University Rotterdam, 3000 DR Rotterdam, The Netherlands

\begin{abstract}
Cities are open to trialing new approaches for advancing their planning and urban governance practice. Evidence from urban research and practice shows that transition management has been widely and diversely applied for strategic planning for climate mitigation and adaptation, regeneration, as well as sectoral (energy, water, waste) and social cohesion agendas. Despite the amounting evidence of the applications of transition management, the research has not identified what it is required in terms of skills to apply such a governance framework for participatory governance in cities. In this paper, we respond to this gap by providing evidence from 11 cities across Europe that applied transition management as an approach to participatory urban governance for unpacking what transformative actions are required to strengthen urban resilience in deprived neighborhoods. Our multi-case study research and analysis reveals that a multitude of vocational and academic skills are required for the application of transition management approach including systems thinking, creativity, theory-to-practice application skills, diplomatic skills for forging partnerships and learning alliances and openness to learning-by-doing during experimentation. Transition management application in cities in the Resilient Europe project brought about positive outcomes in terms of developing new skills, embedding new knowledge about urban resilience and transition management in planning.
\end{abstract}

Keywords: cities; co-creation; skills; transition management; sustainability; urban resilience; systems thinking

\section{Introduction}

Cities are at the forefront of driving transitions to sustainability, livability, and climate resilience [1-3]. Especially European cities face many persistent challenges in their planning practice to achieve sustainable, resilient, and livable futures due to a number of urban characteristics. European cities are diverse in size and urban form; however, in their majority are compact cities with densifying strategies in place, making urban regeneration projects challenging due to the competing interests for the use and function of public urban places and their symbolic meanings. Another characteristic is that many European cities, especially medium-sized cities, have put in place daring climate change adaptation agendas as well as urban infrastructure renewal projects as combined responses to deal with underlying issues (such as social cohesion, urban inequalities, and migration). These urban issues are complex, involve many different actors either because no single actor holds the knowledge nor the innovation required for moving to sustainable solutions in cities, or because these issues require action to be mobilized and realized by a multiple actors or partnerships of actors therein $[3,4]$. At the same time, to understand the heart of the problem requires multiple perspectives to come together and in a facilitated mode to co-create knowledge on new views of the problem and on possible sustainable solutions. In this context, cities need to update their governance practice and open up to new methods and approaches. 
An approach that is proven to advance and complement urban planning tools and methods is transition management [5,6]. Transition management is a governance process methodology informing participatory and reflexive strategic and operational planning in cities for discovering drivers of change, enabling agents of change to collaborate and collaboratively form strategic agendas as well as co-defining and co-creating transformative solutions to commonly understood sustainability challenges [7]. It has a track record of 17 years of applications [6] that vary from heuristic ones to examine and map governance processes, to prescriptive ones in designing governance processes complementary to decision-making processes in cities, regions, and national levels [4,8-10]. Research for the diverse applications of transition management has shown that it is a flexible and valuable framework and that it can bring about strategic results in cities [11-17].

Despite the amounting research and practice of the applications and adaptations of transition management for various urban priorities, the research has not identified what it is required in terms of skills and governance capacities to apply such a governance framework for participatory governance in cities. Earlier research elaborately presents the outcomes and outputs of transition management applications in cities [5], while newer urban applications show how transition management process results in strategic outputs for the city alongside policy learning [18] and a reflection of the various strengths and limitations of the approach is also presented by [16]. From literature reviews on the applications of transition management in cities $[4,6,7,16,17,19-24]$, it is notwithstanding to say that urban practitioners and researchers will benefit from identifying which types of skills and capacities are needed to apply transition management as well as from examining the governance capacities that are built by its application.

It is important to view the research scope of this paper in relation to the recently published report by World Economic Forum [25] that stresses the importance of complex problem solving, creativity, originality and initiative, critical thinking, and analysis for future jobs especially in view of what upskilling, and reskilling will be required for business planning ([25] pp. 150-151) something applicable to local governments. In this paper, it is presented how transition management as a governance approach was applied to design the co-creation of strategic action plans for strengthening urban resilience in deprived neighborhoods in 11 European cities that have urban resilience as climate policy priority. By this rich, multi-case application of transition management in European cities, this study aims to identify and examine which skills and governance capacities are required.

\section{Materials and Methods}

\subsection{The Resilient Europe Project}

The Resilient Europe was founded by European Commission URBACT secretariat and for four years (2015-2018) brought together 11 cities across Europe to work together for examining and discovering in a co-creation mode what the dimensions of urban resilience are and which transformative actions are required to strengthen urban resilience in selected places in these cities. The cities were selected through participatory snowballing: The cities of Rotterdam, Glasgow, and Thessaloniki were initially expressed interest in learning from each other on how to co-design with citizens local actions to strengthen urban resilience. Forming a 'learning alliance' a snowballing process of reaching out to other cities that had already interest or established agendas on urban resilience was realized in autumn and winter of 2015. That resulted in identifying and establishing the engagement of a total of 11 cities of various sizes and different geographies with a strong commitment and interest in learning, exchanging, capacity building and skill development for strategic and tactical action formulation for urban resilience. In result, the selection of cities was not informed by an urban methodology e.g., cities of similar size or socio-economic status but rather cities were selected based on their policy commitment to urban resilience as a climate policy priority. The diversity of sizes, governance capacities, and capabilities as well as diversity of socio-ecological conditions were not selection criteria of these cities. 
With the understanding that urban resilience is a multifaceted challenge, the citiesnetwork actively seeks to unpack the dimensions of resilience in and of cities by looking at how individuals, communities, institutions, businesses, and infrastructures along with urban ecosystems, address current trends and future transitions [26] (see Figure 1). As such, cities at the end of the project had a more comprehensive understanding of the social, ecological, economic, and institutional capacities at present and in the future, that will enhance their ability to foster resilience and thrive in face of adversity and uncertainty.

In the Resilient Europe project, every city focused the participatory experimentation between citizens, businesses, and city officers in a selected deprived neighborhood, as a location in which the city's problems are amplified and the nestedness of the problems is evident socially, economically (with urban poverty percentages being higher than in other neighborhoods), and spatially (with derelict or malfunctioning infrastructure and abandoned or unutilized public spaces). In every neighborhood, engagement with local stakeholders was organized in the form of an urban living lab $[27,28]$ and facilitated with a transition management approach [6,21].

Specifically, we conducted a transdisciplinary research that included co-design and applying and monitoring the application of transition management between researchers and city officers in the following neighborhoods: Sint Antries in Antwerp, Belgium; Lawrence Hill and Easton in Bristol, United Kingdom; Zaleze in Katowice, Polland; Senge Park in Malmo, Sweden; West End in Vejle, Denmark; Pamvotis waterfront district in Ioannina, Greece; City center district in Potenza, Italy; Dolno Ezerovo in Burgas, Bulgaria; Toumba in Thessaloniki, Greece; Ruchill and Possil Park in Glasgow, UK; and Afrikaanderwijk in Rotterdam, The Netherlands. Every city identified an entry point of focus in their living lab to address and learn about actions to put in place for achieving urban resilience. The mapping of the different cities across the three entry points for addressing urban resilience is presented in Figure 2.

What all cities of Resilient Europe had in common is that they started the transition management process with a concise and systematic monitoring and evaluation applying the baseline analysis framework that was set up in 2015. In the baseline analysis, the current situation of every city was described considering demographic, economic, ecological, infrastructural, and organizational/governance aspects and analyzed to identify stresses and shocks across economic, ecological, infrastructural, and governance aspects. This provided the evidence base for justifying the dual objective of the Resilient Europe project: (a) A new perspective is needed to address urban challenges in the form of stresses and shocks, that is systemic and considers long-term processes and goals simultaneously. This new perspective that cities adopted and experimented with is the concept of urban resilience. (b) A place-based operationalization of transition management is required in examining and experimenting with what makes urban resilience in a city.

\subsection{Transdisciplinary Research Framework: Transition Management in Cities}

As a governance approach from sustainability transitions' studies, Transition Management can offer a theoretical and process design basis for bringing together the multiple knowledge holders and stakeholders operating in and for the nexus to create an active knowledge co-production platform. Transition Management is a governance approach for enabling and triggering transformative action that empowers frontrunners and change agents from different sectors and organizations [8,29-35]. As an approach, transition management systematically drives the co-creation of visions, actions, and strategic agendas in the form of transition pathways that can inform and mobilize action on the short-term, medium-term, and long-term, connecting in this way actions of 'here and now' to desirable futures 'there and tomorrow' [24]. With applications in low-carbon climate mitigation and adaptation in cities $[5,17,20]$ and in urban sustainability with the focus on climate adaptation [16] as indicative to how Transition Management can benefit traditional strategic planning. 


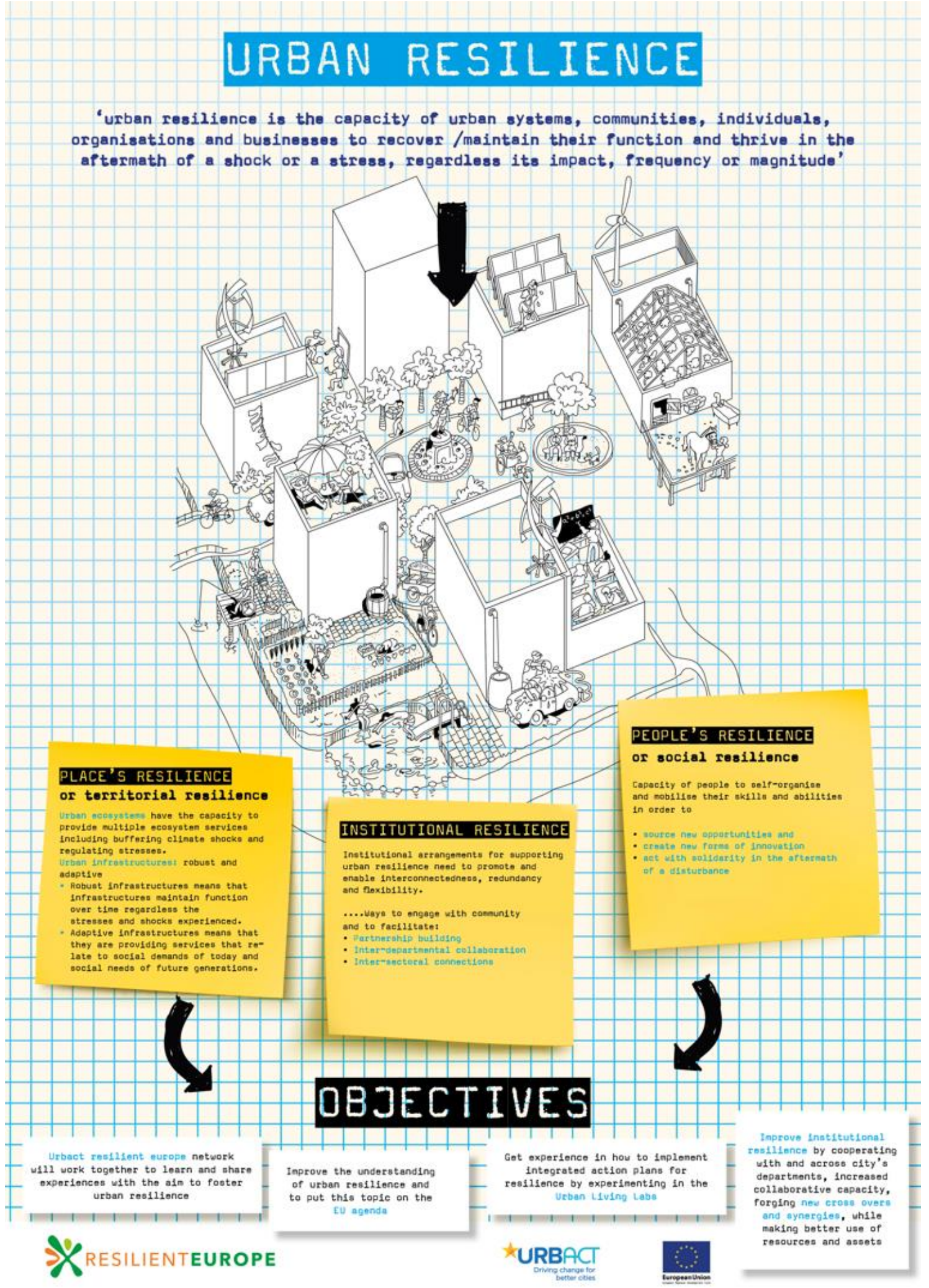

Figure 1. Infographic that captures the conceptual framework of urban resilience developed and applied in the Resilient Europe project (Source: Resilient Europe project). 


\section{PEOPLE}

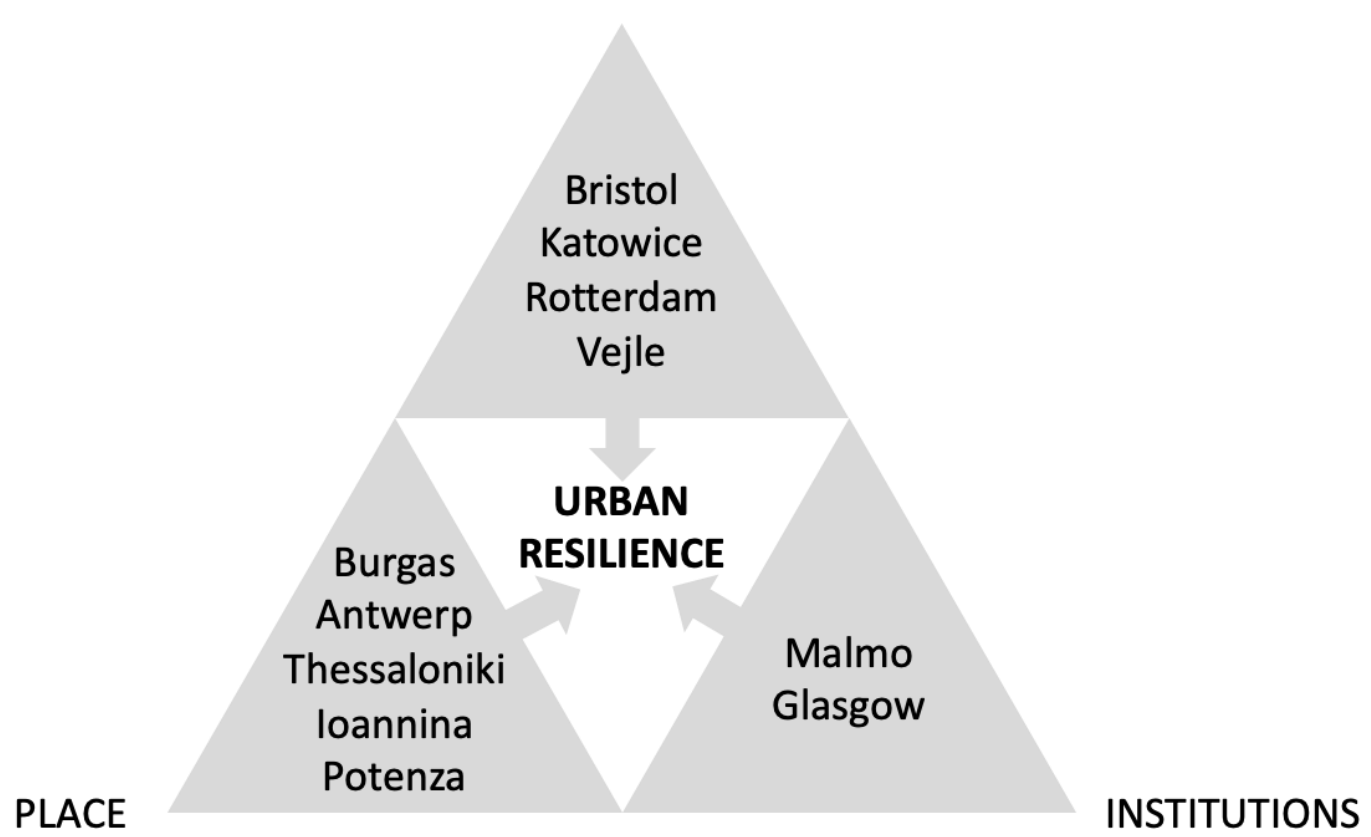

Figure 2. The cities of the Resilient Europe project positioned along the entry point of choice for unpacking urban resilience as well as for designing and working with the urban resilience conceptual framework in the deprived neighborhood of choice.

Transition management proposes a cyclical governance process with multiple types of activities [12,13,21]. The core idea is that four different types of governance activities can be distinguished when observing actor behaviour in the context of societal transitions: strategic, tactical, operational, and reflexive. The activities exhibit specific characteristics in terms of the type of actors involved, the type of process they are associated with, and the outputs they deliver $[6,11,13,22]$. The transition management cycle consists of the following phases:

- Orienting Phase: This phase includes problem structuring, establishing and organizing the transition arena, and envisioning.

- Agenda Setting Phase: This phase includes activities delivering on a transition agenda, a vision of sustainability development and transition pathways. In addition, in this phase the identification, design, and carrying out of transition experiments is realized including, mobilizing additional actors and networks.

- Activating Phase: This phase includes monitoring, evaluating, and learning from the transition experiments and, based on these, making adjustments in the vision, agenda, and coalitions.

The transition management cycle involves many different tools (such as envisioning, backcasting). All the transition management tools are participatory and with an explicit focus to stimulate and/or facilitate innovation (e.g., technological, governance, social innovations) [22,36-38]. To enable transitions, institutional flexibility and innovation in governance should, among other things, build on local knowledge including that of residents and experts. Incorporating citizen knowledge represents a significant step forward, since the citizens not only have to be involved in participatory planning, but also are considered as holders of relevant knowledge useful for preventing and managing risks and understanding how to collaboratively strengthen resilience and just outcomes [39].

In the Resilient Europe project, the transition management approach was introduced extending from the process guidelines that were developed in two previous projects: the MUSIC project [4-6,16,17,19,23] and the Melbourne Urban Water Transition project [18,40]. As such, in this paper we will not repeat the process guidance steps in full detail as those 
already developed and published in earlier work; instead, we will introduce the outcomes of the process and will focus on the activities performed and skills required to realize them. In this way, we aim to engage with the audience of the journal in advancing and enriching planning practice with the practice side of transition management. Specifically, what was further developed with the Resilient Europe project is a step-by-step approach on which types of skills and governance capacities are required during an effective application of the transition management process at local level.

\subsubsection{Orienting Phase}

Identifying the challenge or the opportunity: In this step, a sustainability challenge is identified or recognized that requires new ways of searching for solutions, and new ways of engaging with stakeholders. Another way to start the orienting phase is to recognize or anticipate an opportunity for a new orientation for city making, either at neighborhood or at city-wide level [32,41,42]. An opportunity can, for example, consist of a new framework that can offer an alternative view or perspective to a problem that is recognizable as persisting interventions or the opportunity to join a learning alliance or network with other cities to seek new tools, methods, approaches, or even inspiration for city making.

Envisioning: Envisioning is important for unlocking imagination and creativity for the future we want in cities through narratives, images, artistic expressions [23]. A vision is an expression of the desires of the future state of a city or a locality such as a neighborhood that clearly encapsulates and expresses desires and aspirations, articulates 'what we want' for the future and is valuable operational element that can guide the definition of objectives (that will later formulate the evaluation framework for the action plan of the city) [42,43]. A vision is also valuable as a planning tool since it can be used for explaining the motivations of actions, for selecting between actions proposed to include in the strategic action plan and to further adapt on-going actions over time. A vision can also be of strategic importance to attract attention of otherwise disconnected stakeholders and to trigger transformative thinking [44]. A vision, however, is not a static mark in the future, but can also change over time when new deliberation and co-creation processes come in place to invigorate, enrich, and adapt it. Overall envisioning opens debates on contagious issues while offering the opportunity to re-imagine places and spaces in cities as well as to reposition ideas and understandings of problems as collective imaginaries [45].

\subsubsection{Agenda Setting Phase}

Formulating transition pathways: Pathways is a concept that has entered the discussions in climate adaptation strategy development only recently, specifically, the past seven years. What we have seen from the adoption of the concept of pathways is a change in thinking from sectoral actions to cross-sectoral actions [35,46-48]. Pathways are co-created with transition management methodology, incorporating transformative aspects of actions with the aim to achieve the urban resilience vision.

Experimenting: Setting experiments is a way to learn by doing small scale actions included in the transition pathways. In this way, city officers and cities get first-hand experience and learning from real life daring actions, investigate what the barriers are for transformative actions and the formulated pathways and what institutional arrangements benefit, burden and are required for the takeoff of transition pathways [11,12,24,28]. An experiment is a daring but specific local action that targets to test an idea/technology and learn from the process and results for achieving urban resilience. A meeting, a citymarketing action such as a marketing or awareness campaign, a social media action (e.g., a Facebook page/group), and a voluntary action from an NGO that is 'business as usual', are not experiments. Experiments are to test new ideas and new actions at small scale. An experiment is multi-actor, meaning that it involves local government as one of the actors. It is a simple but effective action to serve as a steppingstone for learning and to show a visible and tangible action that is accessible, invites discussions and debates that alter thinking and perceptions and can be celebrated and owned by the local community. Experiments can 
serve to strengthen commitment to the vision of urban resilience, moving the discussion beyond 'talk-shop' and into learning by doing.

Connecting experiments to urban agendas: In this phase of the transition management cycle, it is important to put effort and think strategically on how the results are communicated: to show the change in mindset that happens when thinking of building urban resilience, from considering shocks and crises as opportunities. Additionally, sharing the results with a broad spectrum of actors created a positive momentum for the cities, especially for those that engaged with younger populations.

\subsubsection{Activating Phase}

It is important to have a continuous reflection and monitoring of the transition management process to harvest on the lessons learnt and, in this way, change/transform the existing planning practice and mindsets about how to make urban resilience in cities $[5,16,19,28,49]$. In the activating phase, transition management theory and practice propose to tailor tools and methods to the planning experience and rationale to ensure that learning is documented, captured, and reflected upon [7].

\subsection{Data Collection Methodology and Methodological Background}

During the Resilient Europe project, we set up a transdisciplinary process that informed the design of every transition management phase and the monitoring of learning from every step to inform the proceeding steps and approaches (Section 2.2). The research was set up to discover the required skills for applying transition management in cities. After completing the transition management activities, from the monitoring and assessing dialogues that were realized with the cities, we confirmed that the mapped required skills were because of the learning by doing process now acquired to the city officers who realized the transition management in their city.

First, we conducted a series of workshops, focus groups, bilateral calls, and meetings and webinars for co-defining with the cities the required skills for applying transition management in cities. The activities (workshops, webinars, and others) are listed in Table A1 in Appendix A. The activities have been designed in an iterative way so as to enhance the learning of transition management by the city officers involved in the process. This is manifested by the progressive curriculum with webinars, on-line and in-person sessions on the same methods as illustrated in Table 1. The training sessions were designed as interactive, following guidelines from interactive and blended learning models that allowed both skill building and skill assessing as dual objectives (following [50]).

Second, for every activity that is described in Table A1 in Appendix A, we had audio and video recordings that were transcribed and pictures of mind-maps and other conceptual diagrams that were developed during the workshop sessions that are considered as primary data for this paper, since the author was directly involved and in a research leading role. The synthesis of the raw empirical data was realized using formal narrative assessment method using two level coding for 'outcomes' and 'skills' manually using MS Excel. The second level of code on 'skills' used the skill outlined in learning code schemes like those in Newell [50] to analyze the narratives from all activities. The skills coding was further informed by the categorization of skills and competences presented in the 'handbook on skills and competences' of the SUSTAIN project (https://sustainedu.com/learningresources (accessed on 6 January 2020)). The coding scheme was in four different languages: English, Greek, Dutch, and Italian. For the coding scheme and its consistency due to translation we consulted a linguistics expert to validate terminological consistency across languages. The narrative analysis illustrated that the 'required' skills that were identified during the process were also recognized as 'acquired' after performing the specific steps and methods in the living labs; hence, in the results we omit the dichotomy between required and acquired. 
Table 1. Required skills for the application of transition management in cities: Results of 11 urban living labs across Europe from the Resilient Europe project (results from data collected and analyzed during the period of 2015-2018).

Transition Management Phases

Skills

Orienting

Agenda Setting
Reflecting \& Monitoring

\section{VOCATIONAL SKILLS}

Thematic Expertise

On transition management

On urban resilience

On evaluation frameworks

Creativity

\section{Critical Thinking}

Identifying multiple actors

\section{Theory application skills}

Connect visual ideas and narratives with places

Apply concept of experiment to place

Apply evaluation framework to process

Collaboration and team work skills

Convening multiple actors

Diplomatic skills

Facilitation of group discussions

Forging partnerships and mobilizing networks

\section{ACADEMIC SKILLS}

\section{Methodological and learning skills}

Systems thinking skills

Openness and receptivity to learn from

experiments

\section{Analytical skills}

Choosing the right medium to communicate

Analyze results from experiment for policy

learning

\section{Oral and written communication skills}

Facilitation of group discussions

Writing results from every phase

and the strategic action plan $\bullet$

$\bullet$

$\bullet$

Third, next to these primary data, we also considered a set of secondary data from the 11 cities. Over the period of four years, the cities engaged with a core group of stakeholders in every neighborhood for the targeted discussions of the urban living lab. In parallel, city officers consisting of the core group driving the transition management process communicated and consulted a broader group of citizens that varied in size again over time and in every neighborhood. We draw from the reporting of every city for their transition management process that was realized with project internal reports over the period of the year, with the formulation of 11 Integrated Action Plans that also report on the process of transition management and 11 in-person monitoring interviews that were realized in March 2018 with the city project coordinators from every city. 


\section{Results}

This section presents a synthesis of the results from 11 cities, applying it in the Resilient Europe project. We present the skills required per phase of transition management cycle with the emphasis of the results. We contend that the list of skills we present is neither exhaustive nor finite and that in other applications of transition management additional or even less skills may be required depending on the design of the process as well as the scope of the transition management process itself (e.g., strategic, operational, tactical). The readiness and the governance capacity of the 11 cities that were involved actively in the research project provided constructive grounds for advancing their practice with learningby-doing transition management and provided us with the opportunity to research on the required skills. Other cities, however, may require more preparation and extensive learning for taking on board transition management in their suite of participatory planning and governance tools. The presented results may therefore provide an overview of the needed skills to be developed while setting up and undergoing a transition management process and, at the same time, can also be seen as the learning outcomes and opportunities for taking on board a transition management for strategic urban planning projects via enabling a learning-by-doing approach.

\subsection{Orienting Phase}

\subsubsection{Identifying the Challenge or Opportunity}

Skills required: Systems thinking. Applying systems thinking at a city level is not new [51]. Conceptualizing cities as interconnected systems provides a framework to map interdependencies, systemically investigate drivers and pressures, as well as to think of integrative solutions and actions beyond dealing with symptoms of problems. This comes in agreement with Mingers and White [52], pointing that applying systems thinking, it is frequently meant "recognising that the relationships or interactions between elements are more important than the elements themselves in determining the behavior of the system". For unveiling a challenge that feeds in and back from stresses and even shocks to systematically map these drivers following resilience thinking approach, one must be able to understand the whole system and how it operates, what drives and sustains identifiable patterns of development. For this, it is important to recognize that the individual parts of the city as a system, e.g., infrastructures, communities, economic flows, jobs, and local markets are in continuous interaction and interdependence and that a change or shock in one, brings non-linear changes in the interdependent parts. Thus, a systemic understanding of the city as a complex system of 'parts' that are in continuous interaction is vital.

An example of how system's thinking was instrumental for identifying challenges and opportunities in Resilient Europe cities comes from the city of Veije in Denmark. During the preparation of the first participant workshop (Transition Management workshop, in December 2015, see Table 1 for details), the city team in collaboration with the author spent significant time in mapping the city-specific and city-wide challenges that relate to urban resilience. We used a systems model (that we extended to identify stressors, pressures, shocks, and opportunities as well as desirable outcomes from a resilient Vejle city. During the full day preparatory meeting taking a systems perspective allowed for identifying the ways different subsystems, such as 'public and green space', 'social housing', 'urban economy and SMEs', and 'urban planning projects and processes', to relate and interconnect. This led to preparing open questions and an engagement program for the first transition arena that were informed by a systems thinking. Applying systems thinking to unpack drivers, stressors, and pressures to the system also led to a reframing of the challenge from 'finding ways to engage citizens' to openly discuss collaborative planning for a resilient Vejle. Lastly, applying a systems thinking enabled the structuring of inputs from stakeholders during the first transition arena (transition management workshop held in December 2015) to the way interrelations and interdependencies have been mapped out, resulting in a richer yet systemic view of the urban challenges and how they relate to achieving urban resilience. 
"It is important to have a holistic approach and to show the added value of system's thinking and working by mapping how different community development approaches and issues connect and relate to each other on the long term. There is a value to a long-term perspective since we tend to work on short-term projects and this (process of transition management) gives us the opportunity to work to the long-term." (City Planner, City of Vejle, Denmark, 30.11.2015)

"We need to find a new approach to openly discuss about invisible stressors. This (system's approach and urban resilience lens) allow for framing it and bringing to the discussion with citizens." (Consultant to the city, City of Vejle, Denmark, 30.11.2015)

One more aspect to consider is that building the skill and knowledge of systems thinking was also useful during the formulation of transition pathways in the activation phase. It was recognized and reflected by all city teams that having a good understanding and systems mapping of the challenges to achieve urban resilience was instrumental and guiding the discussions on integrative solutions and action plans later on in the process. For example, in the city of Glasgow, during the workshop held in January 2016 (see Table 1), it was identified that there are systemic challenges on collaborative governance in the Possil Park area. The systems mapping revealed that:

"There is no comprehensive picture of which services are provided by partnerships and initiatives since these remain unconnected and do not communicate with each other. By looking at it in a holistic way, we can see that the confusion is created by the lack of coordination and the fact that organisations fail to explain what their mission and breadth of support is." (12.01.2016, stakeholder, Glasgow Workshop, Glasgow, Scotland, UK).

This was followed up with discussions during the pathway formulation step on how to strengthen the coordination of initiatives and how to reorient efforts not in creating new organizations and services but rather map systematically the existing ones. As a result of this input that was triggered from systems thinking, the city of Glasgow initiated a forum of all citizen and social services initiatives to respond to this systemic challenge.

Skills required: Identifying and convening with multiple actors: Challenges and opportunities in cities always involve multiple actors. The duality of systems and actors and how they interact and shape each other is a well-known topic in sociology [53] and, one may say, an urban planner's everyday task in a city office. Identifying and engaging with diverse stakeholders was a rather complex task at hand given that cities opted for bottom-up transformative actions for urban resilience. In Resilient Europe, city officers needed to acquire skills on mapping and identifying actors that can represent and work collaboratively in linking all the aspects of urban resilience. This comes in agreement with what Helfgott [54] argues as "experience-based system of understanding", pointing to the importance of engaging with diverse stakeholders, stating: "participation of diverse affected stakeholders is a requirement for scientific rigor since resilience thinkers cannot rest on indefensible claims of objectivity or comprehensiveness". For building on existing expertise of urban planners and taking on board the new frame of 'urban resilience thinking', we co-developed an actor mapping framework that is presented below.

The actor mapping, the actor selection and actor engagement was performed by city officers with consultation of the researchers of the Resilient Europe project. A two-step approach was co-developed with the expert of the project and the cities: first applying a tool for mapping the actors across their knowledge and expertise on the dimensions of urban resilience (social, spatial and infrastructural), and second, developing skills on facilitating their dialogues with transition management (see Box 1). The second step included an understanding of 'which actors can activate and/or carry forward transformative change in the city', connecting in this way the notions of 'transformation and actors with transformative capacity' and the tacit knowledge of place and city's dynamics. Overall, from working with all 11 cities, it is concluded that identifying the actors to work collaboratively requires critical thinking and convening with multiple actors further requires teamwork and collaboration skills. 
Box 1. Actor mapping developed and applied in Resilient Europe for identifying actors to participate in the transition management process.

In the Resilient Europe actor mapping, we combined two sets of criteria and the cities mapped the actors that were envisioned with (i) a transformative role and work and (ii) on the different dimensions of urban resilience. The mapping of actors revealed three aspects:

First, the first application of the actor-mapping tool helped the cities to realize that they have networks in place covering only some dimensions of urban resilience. That led to expressing the need that colleagues from other departments need to be approached so as to find actors working on other aspects of urban resilience. This implies that for a topic such as urban resilience crossdepartmental collaboration is important from early phases of the process of urban experimentation.

Second, the actor mapping using the transition criteria showed that resources and institutional status are not the only criteria to taken into consideration about who can work collaboratively for urban resilience. The actor mapping initiated discussions in every city team about identifying the change makers of the neighborhoods and the supporters in these areas, that led to a shift of thinking about who can be important for collaborative work for urban resilience. Identifying the connectors raised discussions about how to engage with these actors strategically to benefit from them and their networks in implementing the agenda and action plan.

During the actor mapping, we also provided a practice-based list of characteristics of the 'usual suspects' that are to be avoided to put energy in engaging with change agents/makers of the urban neighborhoods. During the workshop in Katowice about actor mapping, we identified that usual suspects are the following:

A 'buddy' in all previous processes, meaning a person that you always invite in processes and projects and starts to have a mindset about these processes that can result in unconstructive or philosophical discussions;

A 'professional' participant, meaning a person who participates in any type of process repeating the same message or standpoint, showing no ability to connect to the objective of the process nor to learn from the participation;

An attention seeker or, simply, the 'louder kid on the block', a person who is unable to engage in a dialogue, comes to open participation processes to distract them by not-engaging statements or accusations to the city,

The 'nice' but not a change-maker person, a person that is always nice to include and invite in participatory processes but unable to or incapable of bringing the results of the process further if needed.

Third, the actor mapping showed a time dimension. The connectors are those actors to be possibly engaged in the process later on, whether the change agents are those critical actors that need to be engaged from the very start even from scoping the urban living lab process in the city. The actor mapping therefore allowed the city teams to plan the actor engagement as a continuous process, that is continuous and iterative rather than static and a one-off process of the urban living lab. Next to this, the actor mapping also served as a tool for the actor engagement and communication strategy of the cities.

\subsubsection{Envisioning}

Skill required: Creativity and imaginary thinking. For co-creating visions, it is important to stimulate the imagination of people towards positive futures. To stimulate creativity and imagination in a participatory setting, city officers need to either train for this skill or engage with external facilitators of this process. In the role of the facilitators and stimulators themselves, they need to be able to think imaginatively themselves, and to open up to future ideas that may seem far reached for the present. To develop this skill, what we saw being effective is reading science fiction books, engaging with arts and creative industry such as performative arts (e.g., theater), as well as attending pedagogical seminars on creative thinking. Another way we recommended and saw effective in instigating creative thinking in this step is to read and be presented with inspirational cases from other cities around the world to open up to new ideas and imaginaries. During the on-line workshop for skill building on envisioning, there were ideas presented from other cities around the globe, on 
the details of facilitation, visual and other material used to trigger creative thinking and imagination, as well as approaches for participatory envisioning that incorporated arts and the creative sector.

Skills required: Connect visual ideas and narratives with places. Making visual ideas, conceptual ideas, and narratives relevant for specific places is an important skill that city makers need to have not only in co-creating visions but also with problems. To enrich this skill of city officers, we had two skill-building exercises: a discussion over vision co-creation in the Katowice partner meeting in 2015 and in a webinar for vision creation methods in 2016. Peer-to-peer learning was the method for the vision creation methods webinar, where the city of Potenza and the city of Antwerp shared how they created the vision, openly discussed the motivations behind choices of methods and facilitation tools and how the 'future walks' workshops took place and got localized in their neighborhoods of intervention.

Vision building and discussing on how to be a future resilient city "is a process that people get ownership of the place, confidence and feel strong citizens not clients of the place." (City Officer, Malmo City, Sweden, 04.12.2015)

It was useful for us "to get knowledge from inspirational cases, to see examples to choose from and in this way, have a dream scenario to steer and trigger imagination." (City Officer, Malmo City, Sweden, 04.12.2015-preparatory meeting)

"The urban living labs approach helped people to focus their energy and creativity to one topic and area instead of keeping it general and vague. This also broke down the barrier to engage people, because people feel strong for their place and their neighborhood in our city." (City Officer, Ioannina City, Greece, 21.03.2018)

Skills required: Facilitation of group discussions. Facilitating discussions with the aim to be inclusive and instigate transformative thinking is essential for experimenting with transition management. Facilitating group discussions entails not only the practical issues of keeping time and ensuring that the agreed questions or issues are discussed but rather that during the discussion time all participants had the time and opportunity to express opinions, ideas, and disagreements and a dialogue was realized. In Resilient Europe, it is found that not all planners and city officers had facilitation skills. Facilitation skills are important to enable slow thinkers and silent participants to feel included and contribute to the discussion. During the on-line training on envisioning (held December 2016, see Table 1 for details), we role-played on ways to facilitate group discussions, how to deal with more 'silent' participants, how to navigate conflicting inputs during an envisioning session, and how to encourage opinion sharing and idea sharing of community groups. All participating city officers identified that facilitating of group discussions as part of a co-creation process (mentioning vision building step of transition management) differs from consultation or information sharing mode that it is frequently the way plans and strategies are communicated to communities and require a 'shift in thinking and operating' that requires skill development.

\subsection{Agenda Setting Phase}

\subsubsection{Formulating Transition Pathways}

Pathways generated in the cities of the Resilient Europe project were all place-specific and cross-sectoral, meaning proposing actions about education, infrastructure, governance, planning and social cohesion, as well as climate change in combinations. This shows a successful application of the concept of pathways for strategic and operational scope of activities. We also defined 'what is not a pathway' to help in co-creating pathways for urban resilience: a project, a single action, or a program are not pathways. It is important to ensure diversity of pathways that refer to re-imagining public spaces and especially streetscapes. These pathways connected with experiments in the cities of Bristol, Vejle, Antwerp, Thessaloniki, and Potenza. Each of these cities reimagined streetscapes differently and in ways that can relate and foster urban resilience from the 'street' up to the city. 
Skills required: Systems thinking for action. For thinking of actions to achieve urban resilience at the local level, participants need to have a systems thinking perspective. Systems thinking can be supported by strong visuals of conceptual frameworks of urban resilience, like the three-entry point framework we developed with Resilient Europe that considered the dimensions of people, ecosystems, and governance/partnerships as foundational for building urban resilience. This framework as well other existing frameworks of urban resilience [26] can guide systems thinking create an opportunity to think about solutions that are integrative, radically changing the system by targeting its feedback loops and other relations as well as systemic factors. To further enrich systems thinking, having knowledge of different frameworks that are based on and built on systems' thinking is a first step. The knowledge of examples of systemic solutions and a full picture description may further stimulate systems thinking. City planners can trigger systems' thinking for action by getting inspired from existing solutions and discussing them from a system's perspective. This may require thematic knowledge on systems thinking therefore a preparation in advance before applying the knowledge to practice. In Resilient Europe, we organized a solutions market in which every city brought different solutions that worked in recent projects to inspire peers to think systematically about solutions and pathways.

An example of how to apply systems thinking for designing integrative action comes from the urban living lab of the city of Thessaloniki, Greece. During the transition arena workshop in Thessaloniki held in April 2017, we used the different dimensions of urban resilience to openly discuss and co-create an action plan with the involved stakeholders for improving the image, use and acceptance of bicycle in the inner city. By opening the discussion to how the different dimensions of social practice, infrastructures and planning and place and environment interact and interrelate, a richer input on integrative actions was realized. Specifically, the stakeholders pointed to the need to stop investing time as well as public funds in sporadic initiatives as those were understood as non-systematic and instead, to put time and effort in actions and approaches that are embedded in the everyday routines of citizens to measure (and have) social impact of the new practice e.g., cycling, walking.

"We need to think on how cycling can be an activity that connects the social with the business domains of our city. We need to stop sporadic initiatives on mobility and see how to promote and adopt bikes/cycling also from the tourism sector." (city officer, Thessaloniki, Greece, 04.04.2017)

Another example of how we instigated systems thinking through sharing of learning experiences and good practices was during the Ioannina partner meeting held in March 2017 , by asking city teams to prepare posters of best practices to share with other cities with the aim to instigate transformative systems thinking for the design of the urban experiments. We provided a template for describing the 'systemic solution' and asked for both visual and written descriptions of these solutions. The template that was developed included five fields: (a) a short description of the solution, to provide a description of what the solution was about; (b) a field to identify the urban challenge the solution was responding to; (c) identifying the biggest barrier in realizing it; (d) sharing which stakeholders were involved in designing and in making the solution; and (e) providing in a concise way why this solution is inspirational for urban resilience from own experience. A total of 43 solution posters were collected, printed, and displayed in the form of a gallery of solutions or, as we named it, a 'systemic solutions market' (see Box 2).

Skills required: Forging partnerships and mobilizing networks. Pathways are representations of collective actions that are cross-sectoral and cross-locational. For pathways to be formulated and to be realized, it is important to mobilize actors and networks beyond the participating actors in the participatory process. A skill that is therefore required is to mobilize networks and actors (the connectors and supporters from the actor mapping) that can bring about the transition pathways. Diplomatic skills are required to explain to different actors the benefits on getting involved in this stage of the process, to have an open narrative that can accommodate even at this stage new insights and to appeal to 
multiple actors and create ownership. Openness to collaborate and collaborative attitude with multiple actors are also crucial skills for enabling partnerships to be created. Communication skills are important for forging partnerships with unusual suspects and foreseeing the common benefits to be drawn from a partnership that has as a mission to realize a transition pathway on the short and medium terms.

Box 2. Systemic Solutions Market Creation. Photos are from Ioannina Partner Meeting, March 2017 (Photocredits: Author).

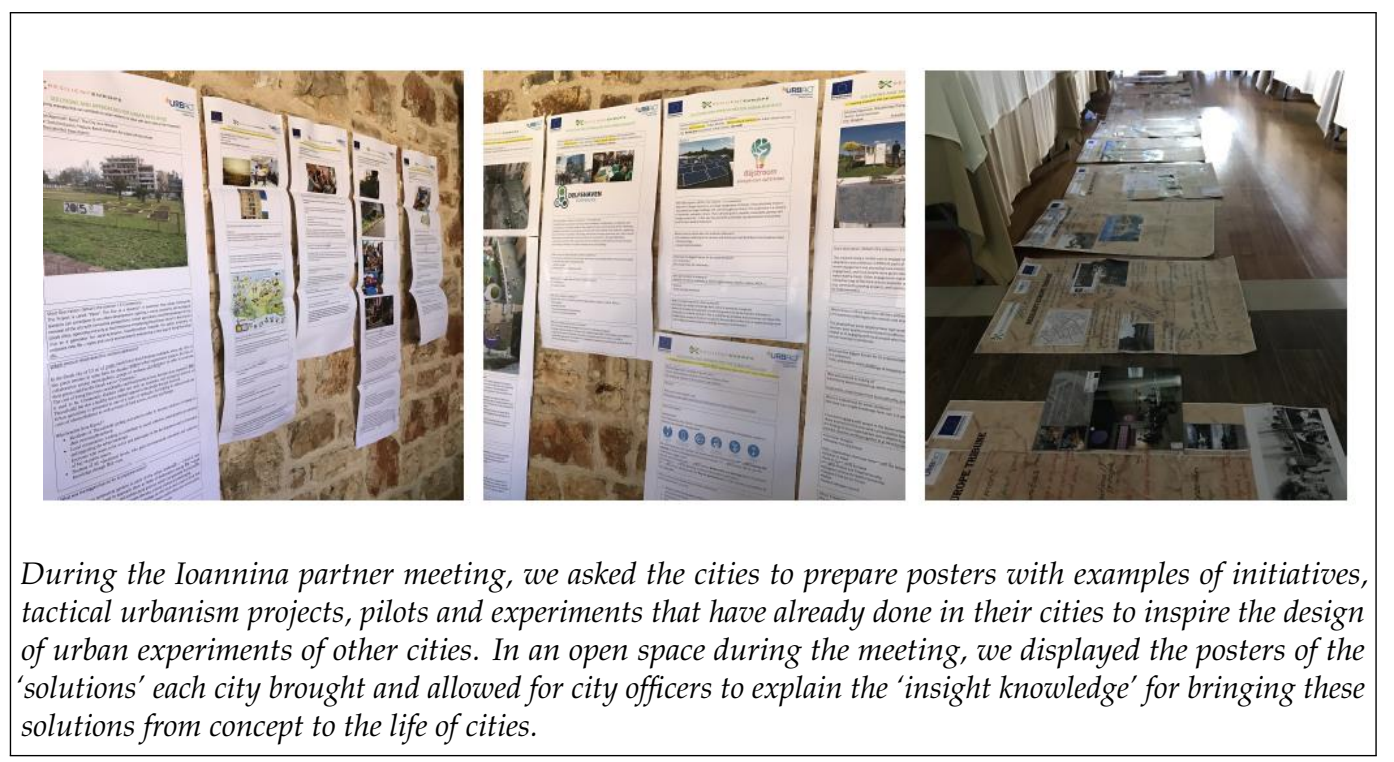

In Resilient Europe, forging partnerships with local community groups was understood and communicated as important by all the cities and especially by the cities of Thessaloniki, Potenza, and Vejle. Especially in the city of Thessaloniki, it was addressed as a necessary skill from early on pointing to the fact that integrative solutions require partnerships to be realized and to be sustained over time. For this, the city officers also pointed to the need for these partnerships to be 'resilient to bipartisanship politics' and to be guided by a common vision.

"For seeing through the plan to increase bike lanes in the city, we need to believe in it and to mobilize those actors that can partner with to collaboratively realise it and to sustain it in the absence of political support or will. It depends on the partnerships to make it happen and we need to build skills to strengthen these partnerships." (city officer, Thessaloniki, 17.12.2015)

It is important during this phase to maintain stakeholders' engagement. There are different ways to ensure that interest in the process is sustained. One way is to keep information flow continuous. Specifically, stakeholders may retain an interest in the process and believe in the vision for urban resilience in the neighborhood; to keep them engaged, the city team that facilitates the urban living lab should continue informing them and keep their attention to the process and outcomes of it. At this phase, it may be important to engage new stakeholders, the connectors and supporters of the vision of urban resilience. The engagement methodology may over time needs to be revised to allow for new actors to be included. An example from the city of Potenza includes the engaging of the Rotary Club and University master's and doctoral students in the process of experimentation for revitalizing the city center neighborhood. The identification of these two actors as essential for realizing and localizing the experiment was made on the grounds of them being mobilizing actors with systems knowledge and local knowledge.

"It is important to involve at this stage the Rotary Club to carry on local activities of the resilience program but now relating it with public and private actors. This is also 
a connecting topic with the University of Basilicata to bring in deeper and systemic

knowledge for change of the city." (City Officer, Potenza City, Italy, 08.02.2016)

\subsubsection{Experimenting}

In Resilient Europe, all cities set in place a number of experiments relating to their proposed pathways for fostering urban resilience. From reviewing their experiences and lessons from the experiments, we draw that the following skills are required for experimenting as a way of urban governance:

Skills required: Openness and receptivity to learn. To valorize the experience with experiments, it is important to enter the process being open to learn and open to question one's own assumptions. It is often the case that openness to learn from the new local experiment allows for more innovative thinking about conditions that may enable the realization of the transition pathway relating to the experiment. At the same time, receptivity to learn, especially laterally, allows for the tacit knowledge of city officers to be enriched and to be also put in action during and post experimentation. Learning through experimentation was a new approach for most of the cities in Resilient Europe project. The cities that had a first-time experience in setting up experiments had a sense of pride for taking up this approach. Specifically, the cities of Katowice and Potenza reported that experimenting allowed them to try out new things outside the regular strict regulatory approaches of their cities. The city of Ioannina also mentioned that experimenting as an approach is rather new for them and it was embraced as a 'safe way' to try new things, to not feel pressure for success and rather learn from mistakes made to open up to new ideas and new approaches for the future of city-making with urban resilience as a reference point. At the same time, experimentation allowed for new narratives for the cities to be co-created (see Figure 3). The narrative of connected spaces and connected city landscapes was co-created in Sint Andries in Antwerp with the green corridor idea as a narrative-imaginative-green infrastructure element to kick-start urban resilience in this neighborhood.

Skills required: Communicating and engaging with citizens. Experiments required city officers to be able to engage openly and creatively with citizens, to communicate with them on the open questions, and to build reciprocity for building trust in the process and in the new relationships. Experiments allowed to test different ways of engaging with citizens in the deprived neighborhoods. The experiments allowed them to try direct ways to approach and communicate with the citizens. For example, Katowice engaged citizens of the Zaleze neighborhood through a food festival, making the issues of social stigmatization and local unemployment directly linked to local talents about food and sweets and showing how to take local action for positive change of place, sense of belonging and community. Another communication skill that was required was in thinking how to present the results of the experiments. The experiments were humanized by bringing forward the 'people of the experiment' more prominently rather than the systemic elements only that the experiment was set to trial or investigate. All cities created narratives from the experiments that presented the human-centered learning and value of engaging in the activity, the social impact and social learning as understood and experienced by the citizens of the urban living lab places (that were the deprived neighborhoods). Humanizing the experiments showed that these experiments were not technocratic fixes to an urban problem but rather socio-technical or socio-ecological interventions that respond to social needs and consider social complexity. Humanizing the transition experiments does not mean to personalize them nor that only specific communities receive the benefits of the experiment. Rather it means that the uniqueness of the experiment is brought to the foreground, it bears a social meaning and community image and, in this way, ameliorating the political coloring of its impact. 


\section{PEOPLE}

Social cohesion and

INSTITUTIONS

activate social innovation

New partnership with community

\begin{tabular}{l}
\hline $\begin{array}{l}\text { Learning } \\
\text { economy }\end{array}$ \\
Community councils \\
Circularity \\
RESILIENCE
\end{tabular}

Figure 3. A presentation of the concepts that were related to urban resilience through learning and experimenting in urban living labs in the Resilient Europe project.

Skills required: Theory application skills. To design and realize an experiment, the city teams first had to develop an understanding of 'what an experiment is' and what its purpose can be in their own city, as well as how it fits the urban agendas on climate resilience. From a theoretical and conceptual understanding of an experiment for urban resilience, planners had then to design and operate the experiment in an open and collaborative way that focused on learning from the process and the results. All cities recognized that during the application of the 'concept' of the experiment in practice, additional dimensions needed to be considered such as: (a) timing of the experiment next to other activities and engagement moments with citizens, (b) establishing collaboration with networks and citizen groups that were not in the direct scope of the experiment but play an important role in communicating and linking the experiment to broader agendas in the city, and (c) finding the ways to 'depoliticize' the experiment from a 'city-driven' to 'citizen-owned' one such as the Biking Day experiment in Thessaloniki city that required a repositioning of the city team to allow schools and sports' association to own the experiment in its execution even though the city team was the main driver of it institutionally and financially. The experiments showed not only unexplored possibilities in steering local action for urban resilience but also the mobilization of social networks that surface social skills, local knowledge, and craftsmanship in responding to urban resilience challenges such as deteriorating social cohesion and unprioritized local employment opportunities. 


\subsubsection{Connecting Experiments to Urban Agendas}

Skills required: Choosing the right medium to communicate. Choosing the right medium to communicate is an analytical skill in matching the available means to communicate with the audience, message, and socio-cultural conditions and momentum when communication is required. We bring forward three modes of communicating the results for other cities to exemplify from. The first is to use social media in a friendly way to reach out to active provocateurs and active coalitions on the same topics that the city wants to work on. The cities of Potenza and Ioannina engaged with Facebook and Twitter communities on social media for attracting people to the urban living labs but also to communicate the results in an easy and citizen-friendly way. Especially the city of Potenza made available results from every urban living lab through social media immediately after every urban living lab workshop. This kept the communication immediate and alive, creating a live-stream model for communicating. The social media communication was an effective way due to the young demographic profile of the city of Potenza and the active engagement with social media of many citizens of the city, that is rather exceptional for small-sized cities. This experience shows that simplicity in communication is the first condition to satisfy; complicated issues of urban agendas need to be easily and simply communicated to the broader audience even to those participating in the urban living lab.

Second, choosing of the medium to communicate requires a careful 'reading' and assessing of the receptivity and accessibility of the city. Some cities choose newspapers and local channels like in Thessaloniki, Ioannina, and Glasgow, whereas more social mediaready cities like Potenza, Ioannina, and Vejle opted for Twitter and Facebook as mediums to share results. Specifically, the cities of Thessaloniki and Ioannina chose the regional TV channels as a means to communicate when urban living lab workshops and open activities were planned to invite more citizens and make the process open to all. The choice of social media appears as cost-effective for cities to share results and engage simply since the platforms of social media exist and the setting up requires only careful positioning and continuous communication as communication skills that almost every city officer has. The city of Ioannina created a blog where they posted the outcomes of every living lab with open question on the opinion sharing of citizens, asking to share ideas on how to progress and allowing for a digital continuation of the narrative development of what was discussed during the urban living lab. This was a very innovative way to openly share and communicate results as well as 'practice what it was preached' that the urban living lab will not serve the interests of a selected few, a criticism during the public debate in Ioannina city in March 2017 (see Table 1).

"Our transition management process and then our urban living lab started with a small group of people that we reached out through our common networks. After the first two workshops we invited through the TV announcement and social media posts the whole city to participate. In total, we had 200 people who participated throughout these two years of the urban living lab and with the blog we opened the dialogue to the entire city." (City officer, Ioannina city, Greece, 22.03.2018).

Third, another lesson comes from the city of Katowice in Poland. The city team created a link between the urban living lab experiences and discussions with an education program from Erasmus Mundus (see Figure 4). This collaboration resulted in designing a version of the monopoly game for Zaleze neighborhood to bring the views and aspirations of children into the strategic discussion for the urban regeneration of the area with the lens of urban resilience. This was a novel way to communicate findings but also to connect the experiment and the lessons learnt to different discussions and activities in the city and specifically in the neighborhood place. 

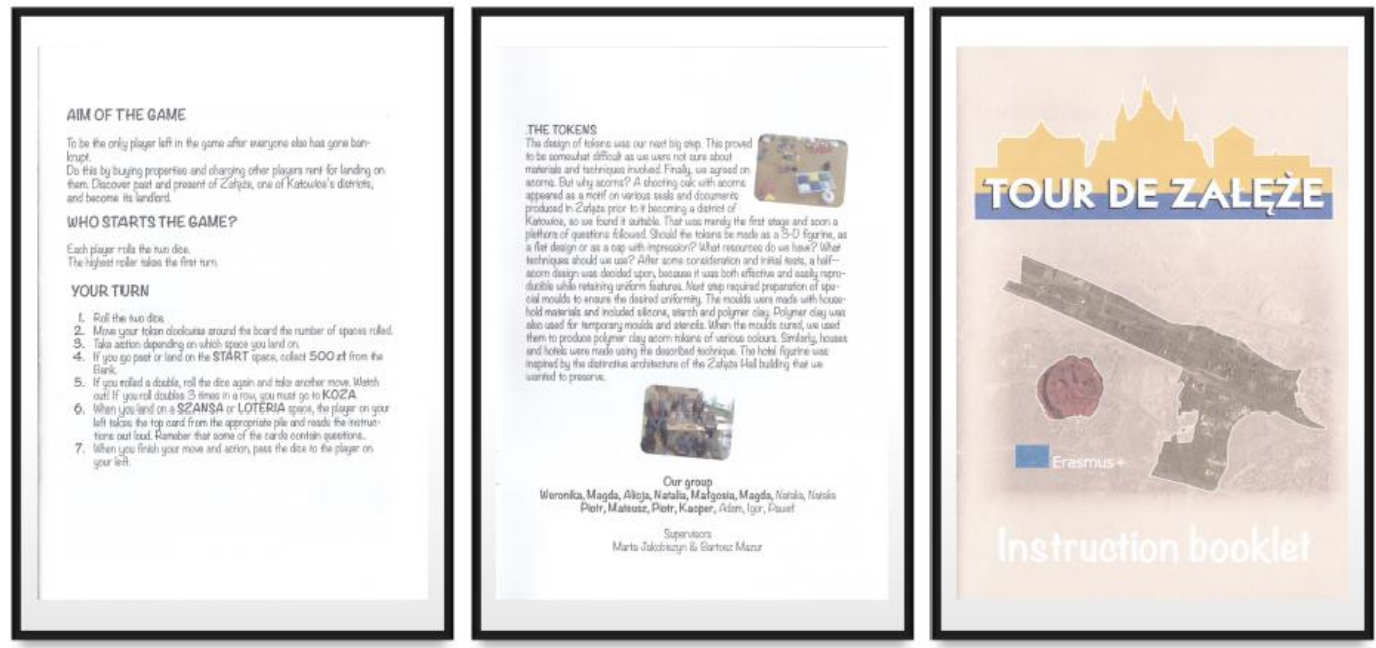

Figure 4. Images from the Instruction Booklet of the Tour de Zaleze board game that was created by the City of Zaleze in cooperation with an Erasmus + research program and its partners (Source: City of Katowice, Poland 2017).

Another way we trialed in the Resilient Europe project to communicate the complex concept of urban resilience is through an artist. During our final partner meeting that took place in Rotterdam city in March 2018, an artist participated in the meeting, in the workshop sessions, and working groups, and captured in a unique way the narrative (or better narrated) understanding of the dimensions of urban resilience by all participating city officers (see Figure 5). We find that involving artists is always an effective way to connect the cognitive understanding with emotions through the visuals created, also realized in previous research with transition management [18].

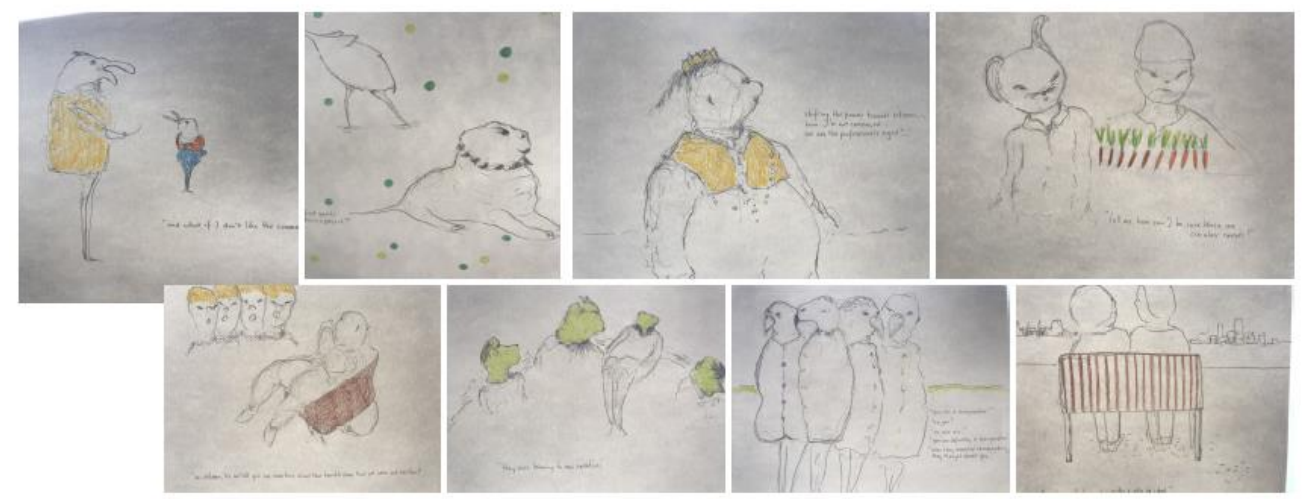

Figure 5. Artistic representation of the multiple dimensions of urban resilience-Initial sketches during Resilience Europe final partner meeting in Rotterdam, The Netherlands, 28.03.2018 (Photocredits: Author).

\subsection{Activating Phase}

Skills required: Theory application skills. City officers can choose from a variety of evaluation tools and methods (e.g., reflexive monitoring [55], transitions monitoring [49]). In Resilient Europe, cities evaluated the results from the experiment with the results framework that is a framework proposed by the URBACT secretariat in using indicators relating to the vision of urban resilience (given the thematic focus of the experiments) to evaluate how far the experiment brought about outcomes to achieve the aspired vision. These required skills to apply theoretical knowledge of the results framework to practice of collecting and systematizing data to evaluate the real-life experience of the experiment. What cities found challenging in this application is the operationalization from vision 
statements to results indicators that can be measurable in real-life situations qualitatively or quantitatively. This required for many cities expert assessment and assistance. The expert assistance was provided via bilateral calls with the city officers and the author as the researcher in the Resilient Europe project that further confirmed the importance of the theory application skills for monitoring and evaluation activities.

During the evaluation talks in 2018 with city officers from all 11 cities of the Resilient Europe project, it was reflected that applying new concepts and frameworks to urban planning was challenging and required to be open to a 'learning-by-doing' approach. What was identified as catalytic was the peer-to-peer learning between cities that was realized during the webinars and during the partner meetings where workshops with other city officers were designed, realized, and reflected upon. This comes in agreement with earlier writings about the importance of collaborative learning for transformative thinking and for transformative approaches to planning and governance to be adopted, trialed, and adapted to local contexts [34,56].

Skills required: Data gathering and analysis skills. For monitoring and evaluating the process of transition management and the experiment that was realized, the skills that are required include a systematic gathering of data and mapping of lessons learnt and the ability to analyze critically the collected data. This is often a team work on evaluation and monitoring since there are multiple lessons learnt and outputs from participatory processes valuable for improving planning practice across different departments of the local government [23]. Analytical skills are further required for recognizing and identifying the lessons learnt from the experiment, given that the evaluation is to be realized in a short period after its completion and recognition that the impacts can span over a longer period.

\section{Conclusions}

First, we conclude that transition management as a governance approach for instigating place-focused transformative actions in cities requires a multitude of skills especially vocational and academic skills. For all the phases of transition management, thematic expertise on transition management and how to operationalize it to fit the local conditions is a key requirement. Next to this, we found that good oral and written communication skills are paramount throughout the transition management process, especially for capturing transformative ideas, sustainability solutions in the making and to consolidate results into a strategic action plan. Table 1 summarizes the skills required during the application of transition management in the 11 cities in Resilient Europe project. By inviting multiple actors, including local change agents and sustainability leaders, it allows a collaborative approach to searching and weaving the knowledge and skills that are required. At the same time, in the Resilient Europe cities we experienced that applying transition management in cities allowed for skill building and capacity enriching also thematically, since city officers, practitioners and planners learnt about urban resilience and transition management in a learning-by-doing mode. That overall added to the experiential learning of the city planners of new concepts and methods. At the same time, city planners can advocate in favor of the application of transition management as an approach that also builds governance capacity in the planning practice as a beneficial approach to consider complementary to other planning tools and frameworks.

Second, transition management as a process methodology to guide experimentation in the urban living lab setting required a place-based operationalization of transition management to identify a process and conditions to foster urban resilience. This placefocused approach was the combination of the urban living lab and transition management. Urban living lab is the concept of experimenting with place-based focus and transition management is the process methodology to guide experimentation. Assessing the 11 cities and their learning journeys during the Resilient Europe project, we say that a place-based approach can create deep policy learning and new experience that at the same time, allows for empowerment and activation of citizens to participate and co-design urban action plans. 
Third, we found that building skills for transition management and trialing a new approach helped city officers (including urban planners) to reflect on social and community program roll-outs and their management. Specifically, in the cities of Malmo, Glasgow, Bristol, and Rotterdam, experimentation in the urban living labs allowed for a different approach to community engagement, to bring transformative thinking in a bottom-up way while engaging with middle-level programs for community empowerment and support. Building skills for systems thinking especially allowed cities in post-industrial transitions to rethink how to bridge the divide between vulnerable communities and new residents attracted to the ICT sector/economy of the city. These cities included Katowice, Bristol, and Malmo, who used the skills developed to open up other city agendas to more experimental approaches and bottom-up engagement with communities.

In this paper, we draw from case study research realized in European cities. Our conclusions and findings relate to the European context including the common institutional conditions as generated by European Union directives and policy schemes as well as the policy-science interface shaped by the research programs and initiatives such as URBACT III program that Resilient Europe project was funded. For replicating or transferring the methodology and research design outside Europe, we suggest three good practices for transdisciplinary researchers as starting points:

- $\quad$ First, be problem- or challenge-driven, meaning that transdisciplinary research on urban resilience can depart from real-life challenges in cities at various scales: district, neighborhood, or city-wide. This implies a scoping phase of problem mapping, identification together with either local governments or communities so as to systematically understand the conditions, drivers, and overall problem dimensions using urban resilience as a lens for analysis and diagnosis [57,58].

- $\quad$ Second, co-design urban living labs interventions with communities of interest that may differ from place to place. In our research project, the local governments showed interest in the experimental approach of urban living labs and were committed to the research design throughout the project. Such commitment and engagement are vital for trust building and for ensuring that transdisciplinary research findings can be actionable and policy relevant [59-61].

- Third, consider the place (the location) in which experiments are to take place and participatory approaches such as transition management can find a 'home'. In order to identify places in cities that can serve as 'experimental grounds' start with public open spaces that can serve as learning laboratories for scientists, citizens, and local governments alike. This is a transferable practice beyond European cities, given research findings from cities across the globe that point to the learning potential of public spaces in cities for encouraging citizen dialogues, activation as well as shifts in environmental behavior. Specifically, "public spaces enable synergistic interaction and exchange, creativity and delight, and the transfer of knowledge and skills. Public spaces can help residents to improve their prosperity, health, happiness and well-being, and to enrich their social relations and cultural life" [58] (p. 199).

These are preconditions before diving into contextualizing and tailoring transition management to local socio-political and cultural conditions. As we have identified at length in earlier research [6], understanding the context in which transition management is to be applied is paramount for its effective application towards learning, capacity building and skills development. This is universally relevant for any city, European or not.

Overall, we contend that transition management application in cities in the Resilient Europe project brought about positive outcomes in terms of developing new skills, embedding new knowledge about urban resilience and transition management in planning, and familiarizing the concept of urban resilience for cities that introduce it to their strategic development and climate agendas.

Considerations for future applications of transition management as well as for adaptation of transition management for strategic urban planning include its conceptual collaboration with design thinking, and risk management for extending the integrative view and the 
systems thinking required especially for co-creating climate and resilience agendas in cities. Especially, future research on experimentation with transition management in European as well as global cities can consider cross-comparative research designs of cities with similar sizes (e.g., to identify whether there are similarities in planning capacities of medium- or small-sized cities) or metropolitan city-regions [62,63]. Other future research possibilities include the examination with a gender perspective the receptivity as well as the difference in building transformative thinking with the experience of transition management as a facilitator or participant in cities [64].

Funding: This research was funded by URBACT III program. Specifically, the Resilient Europe project was funded by the European Union URBACT Secretariat program III, and lasted from 2015 to 2018 .

Institutional Review Board Statement: Not applicable.

Informed Consent Statement: All interviewees have agreed to provide information during the interviews, and they agreed to remain anonymous.

Data Availability Statement: Not applicable.

Acknowledgments: I am grateful for all the cities of the Resilient Europe project that participated in the four years of the project, the stakeholders in all the transition management arenas and learning webinars, as well as the citizens of all 11 cities of Resilient Europe who have been contacted throughout the project to participate, debate, and consult the project expert and city project teams. Special thanks to Rieke Hansen and Cleo Pouw from the Municipality of Rotterdam, the Netherlands, for comments and feedback on previous versions of this work on transition management. I also wish to acknowledge the expert inputs of Chris Roorda from DRIFT and of Ania Rok from ICLEI Europe.

Conflicts of Interest: The author declares no conflict of interest. The funders had no role in the design of the study; in the collection, analyses, or interpretation of data; in the writing of the manuscript, or in the decision to publish the results.

\section{Appendix A}

Table A1. Activities realized in Resilient Europe project to build skills for applying transition management.

\begin{tabular}{|c|c|c|}
\hline Type of Activity & Research and Practice Objectives & $\begin{array}{l}\text { Number of } \\
\text { Participants }\end{array}$ \\
\hline $\begin{array}{l}\text { Focus group-In Person } \\
30 \text { November } 2015 \\
\text { Veijle City, Denmark } \\
\text { (Preparatory) }\end{array}$ & $\begin{array}{l}\text { - Practice Objective: Preparatory focus group on a system's } \\
\text { mapping for challenges and opportunities at city scale for planning } \\
\text { for urban resilience } \\
\text { - Research Objective: Assessing Acquired skills and working } \\
\text { together on a systems' mapping }\end{array}$ & 6 \\
\hline $\begin{array}{l}\text { Workshop-in person } \\
1 \text { December } 2015 \\
5 \text { h } \\
\text { Veijle City, Denmark } \\
\text { (Vejle TM Workshop) }\end{array}$ & $\begin{array}{l}\text { - Practice Objective: First workshop on problem definition and } \\
\text { vision of urban resilience for the area of West End in Vejle } \\
\text { - Research Objective: Assessing Acquired skills }\end{array}$ & $\begin{array}{l}21 \text { stakeholders } \\
5\end{array}$ \\
\hline $\begin{array}{l}\text { Focus group-In Person } \\
4 \text { December } 2015 \\
\text { Malmo City, Sweden } \\
\text { (Preparatory) }^{[3]}\end{array}$ & $\begin{array}{l}\text { - Practice Objective: Preparatory focus group on a system's } \\
\text { mapping for challenges and opportunities at city scale for planning } \\
\text { for urban resilience } \\
\text { - Research Objective: Assessing Acquired skills and working } \\
\text { together on a systems' mapping }\end{array}$ & 7 \\
\hline
\end{tabular}


Table A1. Cont.

\begin{tabular}{|c|c|c|}
\hline Type of Activity & Research and Practice Objectives & $\begin{array}{l}\text { Number of } \\
\text { Participants }\end{array}$ \\
\hline $\begin{array}{l}\text { Workshop-in person } \\
5 \text { June } 2015 \\
4 \text { h } \\
\text { Malmo City, Sweden } \\
\text { (Malmo TM Workshop) }\end{array}$ & $\begin{array}{l}\text { - Practice Objective: Scoping on which neighborhood to locate and } \\
\text { organize the urban living lab for urban resilience in } \\
\text { Malmo-presenting possibilities with choosing Sege Park } \\
\text { - Practice Objective: Problem definition and vision of urban } \\
\text { resilience that is city-wide } \\
\text { - Research Objective: Defining Required skills for envisioning } \\
\text { (positioning) and agenda formulation (activating) }\end{array}$ & 12 \\
\hline Focus group-On line & - Practice Objective: Preparatory focus group on a system's & \\
\hline 15 December 2015 & mapping for challenges and opportunities at city scale for planning & \\
\hline Glasgow City, Scotland & for urban resilience & 5 \\
\hline $\begin{array}{l}2 \mathrm{~h} \\
\text { (Preparatory) } \\
\text { Workshop-in person } \\
17 \text { December } 2015\end{array}$ & $\begin{array}{l}\text { - Research Objective: Assessing Acquired skills and working } \\
\text { together on a systems' mapping }\end{array}$ & \\
\hline $\begin{array}{l}6 \mathrm{~h} \\
\text { Thessaloniki, Greece } \\
\text { (Thessaloniki TM Workshop) }^{\text {[2] }}\end{array}$ & $\begin{array}{l}\text { - Practice Objective: Scoping on which neighborhood to locate and } \\
\text { organize the urban living lab for urban resilience in Thessaloniki } \\
\text { - Practice Objective: Problem definition and vision of urban }\end{array}$ & 28 stakeholders \\
\hline $\begin{array}{l}\text { Workshop-in person } \\
18 \text { December } 2015 \\
8 \text { h } \\
\text { Thessaloniki, Greece } \\
\text { (Thessaloniki TM Workshop) }{ }^{[2]}\end{array}$ & $\begin{array}{l}\text { resilience that is city-wide } \\
\text { - Research Objective: Defining Required skills for envisioning } \\
\text { (positioning) and agenda formulation (activating) }\end{array}$ & 10 city officers \\
\hline $\begin{array}{l}\text { Webinar-On line } \\
6 \text { January } 2016 \\
2 \mathrm{~h} \\
\text { Antwerp, Glasgow, Veijle Cities }\end{array}$ & $\begin{array}{l}\text { - Practice Objective: Preparatory focus group on moving from } \\
\text { system's mapping to preparing for the envisioning session } \\
\text { - Research Objective: Assessing Acquired skills and working } \\
\text { together on consolidating the systems' mapping and on preparing } \\
\text { the envisioning session }\end{array}$ & 6 \\
\hline $\begin{array}{l}\text { Focus group-in person } \\
6 \text { January } 2016 \\
2 \mathrm{~h} \\
\text { Rotterdam City, The Netherlands } \\
\text { (Preparatory) }\end{array}$ & $\begin{array}{l}\text { - Practice Objective: Scoping on which neighborhood to locate and } \\
\text { organize the urban living lab for urban resilience in Rotterdam city } \\
\text { - Practice Objective: Problem definition and vision of urban } \\
\text { resilience that is city-wide } \\
\text { - Research Objective: Defining Required skills for envisioning } \\
\text { (positioning) and agenda formulation (activating) }\end{array}$ & 5 \\
\hline $\begin{array}{l}\text { Workshop-in person } \\
11 \text { January } 2016 \text { \& } 12 \text { January } 2016 \\
\text { Every day for } 4 \text { h } \\
\text { Glasgow city, Scotland } \\
\text { (Glasgow TM Workshop) }\end{array}$ & $\begin{array}{l}\text { - Practice Objective: First workshop on problem definition and } \\
\text { vision of urban resilience for the area of Possil Park in Glasgow } \\
\text { - Research Objective: Assessing Acquired skills }\end{array}$ & 10 \\
\hline $\begin{array}{l}\text { Workshop-in person } \\
15 \text { January } 2016\end{array}$ & $\begin{array}{l}\text { - Practice Objective: First workshop on problem definition and } \\
\text { vision of urban resilience for the area of Laurens Western area in }\end{array}$ & \\
\hline $\begin{array}{l}4 \mathrm{~h} \\
\text { Bristol city, United Kingdom } \\
\text { (Bristol TM Workshop) }\end{array}$ & $\begin{array}{l}\text { Bristol city (note that later on, after the system's mapping, the } \\
\text { neighborhood of the living lab in Bristol city changed) } \\
\text { - Research Objective: Assessing Acquired skills } \\
\text { - Practice Objective: Common outline of transition management }\end{array}$ & 8 \\
\hline $\begin{array}{l}\text { Workshop_in person } \\
23 \text { January } 2016 \\
4 \text { h } \\
\text { Glasgow, Scotland } \\
\text { (Glasgow Partner Meeting) }^{[4]}\end{array}$ & $\begin{array}{l}\text { approach for the urban living labs of Resilient Europe } \\
\text { Cities-operationalizing and localizing the transition } \\
\text { management approach } \\
\text { - Research Objective: Discussing and defining required skills for the } \\
\text { whole transition management cycle with all partner cities as a } \\
\text { scoping activity for the training webinars }\end{array}$ & 17 \\
\hline $\begin{array}{l}\text { Focus Group-in person } \\
\text { 26-27 January } 2016 \\
8 \mathrm{~h} \\
\text { Katowice, Poland } \\
\text { (Katowice TM Workshop) }\end{array}$ & $\begin{array}{l}\text { - Practice Objective: Scoping workshop with city team of Katowice } \\
\text { to identify the location and objective of the urban living lab and } \\
\text { first working group on problem definition for urban resilience } \\
\text { - Research Objectives: Assessing acquired skills for problem } \\
\text { definition (positioning) and defining required Skills for } \\
\text { envisioning (positioning) }\end{array}$ & 10 \\
\hline
\end{tabular}


Table A1. Cont.

\begin{tabular}{|c|c|c|}
\hline Type of Activity & Research and Practice Objectives & $\begin{array}{l}\text { Number of } \\
\text { Participants }\end{array}$ \\
\hline $\begin{array}{l}\text { Focus group-in person } \\
28 \text { January } 2016 \\
5 \mathrm{~h} \\
\text { Burgas, Bulgaria } \\
\text { (Preparatory) }\end{array}$ & $\begin{array}{l}\text { - Practice Objective: Scoping workshop with city team of Burgas to } \\
\text { identify the location and objective of the urban living lab and first } \\
\text { working group on problem definition for urban resilience } \\
\text { - Research Objectives: Assessing acquired skills for problem } \\
\text { definition (positioning) and defining required Skills for } \\
\text { envisioning (positioning) }\end{array}$ & 7 \\
\hline $\begin{array}{l}\text { Workshop-in person } \\
29 \text { January } 2016 \\
6 \mathrm{~h} \\
\text { Burgas, Bulgaria } \\
\text { (Burgas TM Workshop) }\end{array}$ & $\begin{array}{l}\text { - Practice Objective: First workshop on problem definition and } \\
\text { vision of urban resilience for Burgas city, Bulgaria } \\
\text { - Research Objective: Assessing Acquired skills }\end{array}$ & $\begin{array}{l}26 \text { participants } \\
4 \text { city officers }\end{array}$ \\
\hline $\begin{array}{l}\text { Workshop-in person } \\
1 \text { February } 2016 \\
4 \mathrm{~h} \\
\text { Rotterdam, The Netherlands } \\
\text { (Rotterdam Workshop) }\end{array}$ & $\begin{array}{l}\text { - Practice Objective: First workshop on problem definition and } \\
\text { vision of urban resilience for Rotterdam and a place-based } \\
\text { definition for Afrikanderwijk neighborhood } \\
\text { - Research Objective: Assessing Acquired skills }\end{array}$ & $\begin{array}{l}10 \text { participants } \\
3 \text { city officers }\end{array}$ \\
\hline $\begin{array}{l}\text { Focus group-in person } \\
2 \text { February } 2016 \\
2 \mathrm{~h} \\
\text { Antwerp, Belgium } \\
\text { (Preparatory) }\end{array}$ & $\begin{array}{l}\text { - Practice Objective: Scoping workshop with city team of Antwerp } \\
\text { to identify the location and objective of the urban living lab and } \\
\text { first working group on problem definition for urban resilience } \\
\text { - Research Objectives: Assessing acquired skills for problem } \\
\text { definition (positioning) and defining required Skills for } \\
\text { envisioning (positioning) }\end{array}$ & 5 \\
\hline $\begin{array}{l}\text { Workshop-in person } \\
3 \text { February } 2016 \\
3 \text { h } \\
\text { Antwerp, Belgium } \\
\text { (Antwerp TM Workshop) } \\
\text { Workshop-in person } \\
9 \text { February } 2016 \\
6 \text { h } \\
\text { Potenza, Italy } \\
\text { (Potenza TM Workshop) }\end{array}$ & $\begin{array}{l}\text { - Practice Objective: First workshop on the problem definition and } \\
\text { vision of urban resilience for the Saint Andries neighborhood } \\
\text { - Research Objectives: Assessing Acquired skills for problem } \\
\text { definition (positioning) and defining Required Skills for } \\
\text { envisioning (positioning) } \\
\text { - Practice Objective: First workshop on the problem definition and } \\
\text { vision of urban resilience for Potenza city } \\
\text { - Research Objectives: Assessing Acquired skills for problem } \\
\text { definition (positioning) and defining Required Skills for } \\
\text { envisioning (positioning) }\end{array}$ & $\begin{array}{l}17 \text { stakeholders } \\
4 \text { city officers }\end{array}$ \\
\hline $\begin{array}{l}\text { Potenza City Public Debate on Urban } \\
\text { Resilience } \\
9 \text { February } 2017 \\
2 \text { h (in the evening) } \\
\text { (Potenza Public Debate) }\end{array}$ & $\begin{array}{l}\text { - Practice Objective: Opening the dialogue on ways to engage with } \\
\text { citizens to co-create a vision and open the discussion for localizing } \\
\text { the concept of urban resilience in the city of Potenza } \\
\text { - Research Objective: Assess the extend of dialogue and } \\
\text { engagement skills for public debate and public participation of the } \\
\text { city officers of Potenza city }\end{array}$ & $\begin{array}{l}58 \text { stakeholders } \\
\text { and } \\
6 \text { city officers } \\
\text { including the } \\
\text { mayor and } \\
\text { deputy mayor }\end{array}$ \\
\hline $\begin{array}{l}\text { Focus Group_in person } \\
12 \text { February } 2016 \\
4 \mathrm{~h} \\
\text { Ioannina, Greece } \\
\text { (Preparatory) }\end{array}$ & $\begin{array}{l}\text { - Practice Objective: Scoping workshop with city team of Ioannina } \\
\text { to identify the location and objective of the urban living lab and } \\
\text { first working group on problem definition for urban resilience } \\
\text { - Research Objectives: Assessing acquired skills for problem } \\
\text { definition (positioning) and defining required skills for } \\
\text { envisioning (positioning) }\end{array}$ & $T^{1}-a^{2}$ \\
\hline $\begin{array}{l}\text { Webinar-on-line } \\
\text { 22 June } 2016 \\
2 \mathrm{~h} \\
\text { All cities }\end{array}$ & $\begin{array}{l}\text { - Practice Objective: Actor Mapping-Tool explanation and skill } \\
\text { development (interactive training session) } \\
\text { - Research objective: Assessing acquired skills by having interactive } \\
\text { dialogue on tools and methods }\end{array}$ & 7 \\
\hline
\end{tabular}


Table A1. Cont.

\begin{tabular}{|c|c|c|}
\hline Type of Activity & Research and Practice Objectives & $\begin{array}{l}\text { Number of } \\
\text { Participants }\end{array}$ \\
\hline $\begin{array}{l}\text { Workshop-in-person } \\
21 \text { September } 2016 \\
2 \mathrm{~h} \\
\text { Katowice, Poland } \\
\text { (Katowice Partner Meeting) }\end{array}$ & $\begin{array}{l}\text { Practice Objectives: } \\
\text { - Actor Mapping and Stakeholder Engagement } \\
\text { - Reflection session aiming to distill lessons learnt and improve } \\
\text { actor mapping } \\
\text { - Envisioning-Introduction to method, approaches, tools } \\
\text { - Session also included sharing lessons from cities about envisioning } \\
\text { to encourage open discussion on acquired skills and tools } \\
\text { - Training about stakeholder engagement and identifying major } \\
\text { obstacles and opportunities for involving urban change agents } \\
\text { - Research Objectives: Assessing acquired skills from doing actor } \\
\text { mapping after the webinar and for envisioning to prepare the } \\
\text { webinar on envisioning (project period 06.2016-09.2016) }\end{array}$ & 44 \\
\hline $\begin{array}{l}\text { Webinar-on-line } \\
\text { Envisioning } \\
6 \text { December } 2016 \\
2 \mathrm{~h} \\
\text { All cities }\end{array}$ & $\begin{array}{l}\text { Practice Objectives: } \\
\text { - Training on Envisioning based on the identified required skills } \\
\text { discussed in the Katowice Partner meeting } \\
\text { - Advancement on the method with the three approaches and } \\
\text { introduction to facilitation skills } \\
\text { - Research Objective: Identify required skills for envisioning and } \\
\text { facilitation of workshops and challenging participants to } \\
\text { these workshops }\end{array}$ & 12 \\
\hline $\begin{array}{l}\text { Monitoring and Evaluation } \\
\text { Calls-on-line } \\
\text { * each call } 1 \text { h per city team } \\
16 \text { January } 2017,18 \text { January } 2017,19 \\
\text { January } 2017 \text { \& } 3 \text { February } 2017 \text { \& } 9 \\
\text { February } 2017 \\
\text { Cities of: Potenza, Malmo, Antwerp, } \\
\text { Ioannina, Glasgow, Bristol, Vejle, } \\
\text { Katowice, Thessaloniki and Rotterdam } \\
10 \text { h in total }\end{array}$ & $\begin{array}{l}\text { Practice Objectives: } \\
\text { - Discussing learning needs for the activation phase of transition } \\
\text { management on formulation pathways } \\
\text { - Identification of theoretical knowledge needs on identifying } \\
\text { solutions and on preparing for co-creating pathways with } \\
\text { stakeholders in the urban living labs } \\
\text { - Research Objective: Assess the knowledge capacities and map the } \\
\text { skills required for the activation phase of transition management }\end{array}$ & 25 \\
\hline $\begin{array}{l}\text { Ioannina City Public Debate on Urban } \\
\text { Resilience } \\
27 \text { March } 2017 \\
5 \text { h } \\
\text { Ioannina, Greece } \\
\text { (Ioannina Public Debate) }\end{array}$ & $\begin{array}{l}\text { - Practice Objective: Opening the dialogue on ways to engage with } \\
\text { citizens to co-create solutions for urban resilience in the city } \\
\text { of Ioannina } \\
\text { - Research Objective: Assess the (extend of lack of) dialogue and } \\
\text { engagement skills for public debate and public participation of the } \\
\text { City of Ioannina }\end{array}$ & $\begin{array}{l}185 \\
\text { stakeholders } \\
\text { and } \\
10 \text { city officers } \\
\text { including the } \\
\text { mayor and } \\
\text { deputy mayor }\end{array}$ \\
\hline $\begin{array}{l}\text { Workshop-in person } \\
28 \text { March } 2017 \\
8 \mathrm{~h} \\
\text { Ioannina, Greece } \\
\text { (Ioannina Partner Meeting) }\end{array}$ & $\begin{array}{l}\text { - Practice Objective: Common outline of transition management } \\
\text { approach for formulating pathways and connecting the lessons } \\
\text { from the experiments to the pathways } \\
\text { - Research Objective: Discussing and defining required skills for the } \\
\text { formulation of pathways and experiments with all partner cities as } \\
\text { a scoping activity for the following training webinars }\end{array}$ & 25 \\
\hline $\begin{array}{l}\text { Workshop-in person } \\
31 \text { March } 2017 \\
7 \mathrm{~h} \\
\text { Thessaloniki, Greece } \\
\text { (Thessaloniki TM Workshop) }\end{array}$ & $\begin{array}{l}\text { - Practice Objective: Identifying actions that can be enriched as } \\
\text { transition pathways for urban resilience of the area of Toumpa in } \\
\text { Thessaloniki city, Greece } \\
\text { - Research Objective: Identifying knowledge needs and facilitation } \\
\text { needs for formulating pathways and place-based experiments } \\
\text { related to it in Toumpa area, Thessaloniki, Greece }\end{array}$ & $\begin{array}{l}22 \text { stakeholders } \\
5 \text { city officers }\end{array}$ \\
\hline $\begin{array}{l}\text { Webinar on Transition Pathways } \\
21 \text { April } 2017 \\
1 \mathrm{~h} \\
\text { All cities }\end{array}$ & $\begin{array}{l}\text { Defining and establishing a methodology for co-creating } \\
\text { transition pathways } \\
\text { - Practice Objective: Training on new method of pathways } \\
\text { - Research objective: Identify required skills for developing } \\
\text { transition pathways }\end{array}$ & 11 \\
\hline
\end{tabular}


Table A1. Cont.

\begin{tabular}{|c|c|c|}
\hline Type of Activity & Research and Practice Objectives & $\begin{array}{l}\text { Number of } \\
\text { Participants }\end{array}$ \\
\hline $\begin{array}{l}\text { Webinar } \\
\text { Results Framework } \\
4 \text { July } 2017 \\
2 \mathrm{~h} \\
\text { All cities } \\
\text { Workshop-in person } \\
21 \text { March } 2018 \\
8 \text { h } \\
\text { Partner meeting in Rotterdam city, The } \\
\text { Netherlands } \\
\text { (Partner meeting) } \\
\text { All cities }\end{array}$ & $\begin{array}{l}\text { Defining and establishing a methodology for setting up a transition } \\
\text { experiment that is objective specific (following the three } \\
\text { interrelated dimensions of urban resilience) and place-based (in the } \\
\text { urban living lab neighborhood) } \\
\text { - Practice Objective: Training on new method of co-designing urban } \\
\text { transition experiments } \\
\text { - Research objective: Identify required skills for developing } \\
\text { transition experiments } \\
\text { Organized an open-discussion webinar in which every city } \\
\text { presented their experiment and were asked to reflect on the lessons } \\
\text { learnt, aspects that informed the integrated action plan for urban } \\
\text { resilience and how it can be connected to other urban agendas } \\
\text { - Practice Objective: Training on incorporating a step of reflecting } \\
\text { and monitoring urban experiments as part of urban action } \\
\text { planning cycle } \\
\text { - Research objective: Identify required skills for monitoring } \\
\text { and evaluating } \\
\text { - Practice Objective: Introducing and explaining how to apply the } \\
\text { results framework for monitoring the transition experiments } \\
\text { - Practice Objective: Training on new method of the results } \\
\text { framework as an evaluation framework for the action plan on } \\
\text { urban resilience } \\
\text { - Research objective: Identify required skills for applying the results } \\
\text { framework in planning practice }\end{array}$ & 35 \\
\hline
\end{tabular}

Notes: ${ }^{11}$ The transition management process is fundamentally a co-creation and co-learning process. In this column, we report the number of participants in every activity undertaken in the Resilient Europe project. When

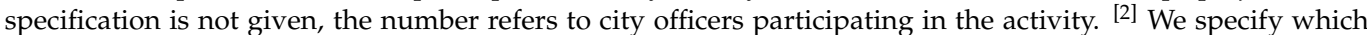
activity is part of the Transition Management Process by naming them as TM Workshop. All TM Workshops include stakeholders and city officers of the city team. ${ }^{[3]}$ We specify which activity is preparatory to a Transition Management Workshop (TM Workshop) as part of outlining the activities required to build skills, test ideas, and co-design the TM workshops with the city teams and experts involved. These activities are specified as (Preparatory). ${ }^{[4]}$ Partner meetings were annual events where all partners were meeting to discuss progress of the project. All partner meetings were set up with specific learning objectives in mind, with sessions around the specific methods of Transition Management and for developing the skills required in the different steps and phases of Transition Management.

\section{References}

1. Frantzeskaki, N.; Broto, V.C.; Coenen, L.; Loorbach, D. (Eds.) Urban Sustainability Transitions; Routledge: New York, NY, USA, 2017; pp. 1-20. ISBN 978-0-415-78418-4.

2. Wolfram, M. Conceptualizing urban transformative capacity: A framework for research and policy. Cities 2016, 51, 121-130. [CrossRef]

3. Hölscher, K.; Frantzeskaki, N. Perspectives on urban transformation research: Transformations in, of, and by cities. Urban Transform. 2021, 3, 2. [CrossRef]

4. Hölscher, K.; Wittmayer, J.M.; Avelino, F.; Giezen, M. Opening up the transition arena: An analysis of (dis)empowerment of civil society actors in transition management in cities. Technol. Forecast. Soc. Chang. 2019, 145, 176-185. [CrossRef]

5. Nevens, F.; Frantzeskaki, N.; Loorbach, D.; Gorissen, L. Urban Transition Labs: Co-creating transformative action for sustainable cities. J. Clean. Prod. 2013, 50, 111-122. [CrossRef]

6. Frantzeskaki, N.; Holscher, K.; Bach, M.; Avelino, F. Co-Creating Sustainable Urban Futures-A Primer on Transition Management in Cities; Springer: Berlin, Germany, 2018; ISBN 978-3-319-69271-5. 
7. Hölscher, K.; Frantzeskaki, N. (Eds.) Transformative Climate Governance. A Capacities Perspective to Systematize, Evaluate and Guide Climate Action; Palgrave Macmillan: London, UK, 2020. [CrossRef]

8. Ernst, L.; de Graaf-Van Dinther, R.E.; Peek, G.J.; Loorbach, D.A. Sustainable urban transformation and sustainability transitions: Conceptual framework and case study. J. Clean. Prod. 2016, 112, 2988-2999. [CrossRef]

9. Loorbach, D.; Frantzeskaki, N.; Avelino, F. Sustainability Transitions Research: Transforming Science and Practice for Societal Change. Annu. Rev. Environ. Resour. 2017, 42, 599-626. [CrossRef]

10. Kumar, A. Transition management theory-based policy framework for analyzing environmentally responsible freight transport practices. J. Clean. Prod. 2021, 294, 126209. [CrossRef]

11. Loorbach, D. Transition Management. New Mode of Governance for Sustainable Development. Ph.D. Thesis, Erasmus Universiteit Rotterdam, Rotterdam, The Netherlands, 2007.

12. Loorbach, D. Transition Management for Sustainable Development: A Prescriptive, Complexity-Based Governance Framework Gov. Int. J. Policy Adm. Inst. 2010, 23, 161-183. [CrossRef]

13. Loorbach, D.; Frantzeskaki, N.; Huffenreuter, L.R. Transition management: Taking stock from governance experimentation. J. Corp. Citizsh. 2015, 2015, 48-66. [CrossRef]

14. Nagorny-Koring, N.C.; Nochta, T. Managing urban transitions in theory and practice-The case of the Pioneer Cities and Transition Cities projects. J. Clean. Prod. 2018, 175, 60-69. [CrossRef]

15. Tàbara, J.D.; Cots, F.; Pedde, S.; Hölscher, K.; Kok, K.; Lovanova, A.; Lourenço, T.C.; Frantzeskaki, N.; Etherington, J. Exploring Institutional Transformations to Address High-End Climate Change in Iberia. Sustainability 2018, 10, 161. [CrossRef]

16. Wittmayer, J.M.; van Steenbergen, F.; Rok, A.; Roorda, C. Governing sustainability: A dialogue between Local Agenda 21 and transition management. Local Environ. 2016, 21, 939-955. [CrossRef]

17. Nevens, F.; Roorda, C. A climate of change: A transition approach for climate neutrality in the city of Ghent (Belgium). Sustain Cities Soc. 2013, 10, 112-121. [CrossRef]

18. Ferguson, B.; Frantzeskaki, N.; Brown, R. A strategic program for transitioning to a water sensitive city. Landsc. Urban Plan. 2013, 117, 32-45. [CrossRef]

19. Roorda, C.; Wittmayer, J.; Henneman, P.; van Steenbergen, F.; Frantzeskaki, N. Transition Management in the Urban Context: Guidance Manual, DRIFT; Erasmus University Rotterdam: Rotterdam, The Netherlands, 2014.

20. Poustie, M.S.; Frantzeskaki, N.; Brown, R.R. A transition scenario for leapfrogging to a sustainable urban water future in Port Vila, Vanuatu. Technol. Forecast. Soc. Chang. 2016, 105, 129-139. [CrossRef]

21. Loorbach, D.; Rotmans, J. The practice of transition management: Examples and lessons from four distinct cases. Futures 2010, 42, 237-246. [CrossRef]

22. Hyysalo, S.; Marttila, T.; Perikangas, S.; Auvinen, K. Codesign for transitions governance: A mid-range pathway creation toolset for accelerating sociotechnical change. Des. Stud. 2019, 63, 181-203. [CrossRef]

23. Frantzeskaki, N.; Tefrati, N. A transformative vision unlocks the innovative potential of Aberdeen City, UK. In Governance of Urban Sustainability Transitions. European and Asian Experiences; Loorbach, D., Wittmayer, J.M., Shiroyama, H., Fujino, J., Mizuguchi, S., Eds.; Springer: Tokyo, Japan; Berlin/Heidelberg, Germany, 2016; pp. 49-68.

24. Frantzeskaki, N.; Loorbach, D.; Meadowcroft, J. Governing transitions to sustainability: Transition management as a governance approach towards pursuing sustainability. Int. J. Sustain. Dev. 2012, 15, 19-36. [CrossRef]

25. World Economic Forum. The Future of Jobs Report 2020. 2020. Available online: www.weforum.org (accessed on 1 December 2021).

26. McPhearson, T.; Andersson, E.; Elmqvist, T.; Frantzeskaki, N. Resilience of and through ecosystem services. Ecosyst. Serv. 2015, 12, 152-156. [CrossRef]

27. Bulkeley, H.; Coenen, L.; Frantzeskaki, N.; Hartmann, C.; Kronsell, A.; Mai, L.; Marvin, S.; McCormick, K.; van Steenbergen, F.; Palgan, Y.V. Urban living labs: Governing urban sustainability transitions. Curr. Opin. Environ. Sustain. 2016, 22, 13-17. [CrossRef]

28. Von Wirth, T.; Fuenfschilling, L.; Frantzeskaki, N.; Coenen, L. Impacts of urban living labs on sustainability transitions: Mechanisms and strategies for systemic change through experimentation. Eur. Plan. Stud. 2019, 27, 229-257. [CrossRef]

29. Avelino, F. Empowerment and the challenge of applying transition management to ongoing projects. Policy Sci. 2009, 42, 369-390. [CrossRef]

30. Bos, J.J.; Brown, R.R. Governance experimentation and factors of success in socio-technical transitions in the urban water sector. Technol. Forecast. Soc. Change 2012, 79, 1340-1353. [CrossRef]

31. Foxon, T.; Reed, M.S.; Stringer, L.C. Governing long-term social-ecological change: What can the adaptive management and transition management approaches learn from each other? Environ. Policy Gov. 2009, 19, 3-20. [CrossRef]

32. Harlow, J.; Johnston, E.; Hekler, E.; Yeh, Z. Fostering Sustainability Transitions by Designing for the Convergence of Policy Windows and Transition Arenas. Sustainability 2018, 10, 2975. [CrossRef]

33. Loorbach, D. To Transition! Governance Panarchy in the New Transformation; Inaugural Lecture, Erasmus Universiteit Rotterdam: Rotterdam, The Netherlands, 2014.

34. Malekpour, S.; Walker, W.E.; de Haan, FJ.; Frantzeskaki, N.; Marchau, V.A. Bridging Decision making under uncertainty (DMDU) and transition management (TM) to improve strategic planning for sustainable development. Environ. Sci. Policy 2020, 107, 158-167. [CrossRef] 
35. Peterson, H.M.; Baker, L.A.; Aggarwal, R.M.; Boyer, T.H.; Chan, N.I. A transition management framework to stimulate a circular phosphorus system. Environ. Dev. Sustain. 2021. [CrossRef] [PubMed]

36. Scuttari, A.; Volgger, M.; Pechlaner, H. Transition management towards sustainable mobility in Alpine destinations: Realities and realpolitik in Italy's South Tyrol region. J. Sustain. Tour. 2016, 24, 463-483. [CrossRef]

37. Schäpke, N.; Omann, I.; Wittmayer, J.M.; Van Steenbergen, F.; Mock, M. Linking Transitions to Sustainability: A Study of the Societal Effects of Transition Management. Sustainability 2017, 9, 737. [CrossRef]

38. Soma, K.; Dijkshoorn-Dekker, M.; Polman, N. Stakeholder contributions through transitions towards urban sustainability. Sustain. Cities Soc. 2018, 37, 438-450. [CrossRef]

39. Goddard, G.; Farrelly, M. Just transition management: Balancing just outcomes with just processes in Australian renewable energy transitions. Appl. Energy 2018, 225, 110-123. [CrossRef]

40. Ferguson, B.; Brown, R.; Frantzeskaki, N.; de Haan, F.J.; Deletic, A. The enabling institutional context for integrated water management: Lessons from Melbourne. Water Res. 2014, 47, 7300-7314. [CrossRef] [PubMed]

41. Tillie, N.; Beurden, J.B.-V.; Doepel, D.; Aarts, M. Exploring a Stakeholder Based Urban Densification and Greening Agenda for Rotterdam Inner City-Accelerating the Transition to a Liveable Low Carbon City. Sustainability 2018, 10, 1927. [CrossRef]

42. Iden, J.; Methlie, L.B.; Christensen, G.E. The nature of strategic foresight research: A systematic literature review. Technol. Forecast. Soc. Chang. 2017, 116, 87-97. [CrossRef]

43. Hebinck, A.; Vervoort, J.M.; Hebinck, P.; Rutting, L.; Galli, F. Imagining transformative futures: Participatory foresight for food systems change. Ecol. Soc. 2018, 23, 16. [CrossRef]

44. Panetti, E.; Parmentola, A.; Wallis, S.; Ferretti, M. What drives technology transitions? An integration of different approaches within transition studies. Technol. Anal. Strat. Manag. 2018, 30, 993-1014. [CrossRef]

45. Sarpong, D.; Maclean, M.; Alexander, E. Organizing strategic foresight: A contextual practice of 'way finding'. Futures 2013, 53, 33-41. [CrossRef]

46. Butler, J.; Suadnya, W.; Puspadi, K.; Sutaryono, Y.; Wise, R.; Skewes, T.; Kirono, D.; Bohensky, E.; Handayani, T.; Habibi, P.; et al Framing the application of adaptation pathways for rural livelihoods and global change in eastern Indonesian islands. Glob. Environ. Change 2014, 28, 368-382. [CrossRef]

47. Liebmann, H.; Kuder, T. Pathways and Strategies of Urban Regeneration—Deindustrialized Cities in Eastern Germany. Eur. Plan. Stud. 2012, 20, 1155-1172. [CrossRef]

48. Wise, R.; Fazey, I.; Smith, M.S.; Park, S.; Eakin, H.; Van Garderen, E.A.; Campbell, B. Reconceptualising adaptation to climate change as part of pathways of change and response. Glob. Environ. Chang. 2014, 28, 325-336. [CrossRef]

49. Luederitz, C.; Schäpke, N.; Wiek, A.; Lang, D.J.; Bergmann, M.; Bos, J.; Burch, S.; Davies, A.; Evans, J.; König, A.; et al. Learning through evaluation-A tentative evaluative scheme for sustainability transition experiments. J. Clean. Prod. 2017, 169, 61-76. [CrossRef]

50. Newell, R.J. Passion for Learning. How Project Based Learning Meets the Needs of 21st Century Students; Rowman and Littlefield Education: Oxford, UK, 2013

51. Forrester, J. Urban Dynamics; MIT Press: Cambridge, MA, USA, 1969.

52. Mingers, J.; White, L. A review of the recent contribution of systems thinking to operational research and management science. Eur. J. Oper. Res. 2010, 207, 1147-1161. [CrossRef]

53. Giddens, A. The Constitution of Society, Outline of the Theory of Structuration; University of California Press: Berkeley, CA, USA, 1984.

54. Helfgott, A. Operationalising systemic resilience. Eur. J. Oper. Res. 2018, 268, 852-864. [CrossRef]

55. Beers, P.J.; Van Mierlo, B. Reflexivity and Learning in System Innovation Processes. Sociol. Rural. 2017, 57, 415-436. [CrossRef]

56. Frantzeskaki, N.; Rok, A. Co-producing urban sustainability transitions knowledge with community, policy and science. Environ. Innov. Soc. Trans. 2018, 29, 47-51. [CrossRef]

57. Schaeffer Caniglia, B.; Vallee, M.; Frank, B. (Eds.) Resilience, Environmental Justice and the City; Routledge: New York, NY, USA, 2018; ISBN 978-1-138-31587-7.

58. Kelbaugh, D. The Urban Fix, Resilient Cities in the War Against Climate Change, Heat Islands and Overpopulation; Routledge: New York, NY, USA, 2019; ISBN 978-0-367-17570-2.

59. Newig, J.; Jahn, S.; Lang, D.J.; Kahle, J.; Bergmann, M. Linking modes of research to their scientific and societal outcomes. Evidence from 81 sustainability-oriented research projects. Environ. Sci. Policy 2019, 101, 147-155. [CrossRef]

60. Turnhout, E.; Metze, T.; Wyborn, C.; Klenk, N.; Louder, E. The politics of co-production: Participation, power, and transformation. Curr. Opin. Environ. Sustain. 2019, 42, 15-21. [CrossRef]

61. Pardo-Bosch, F.; Cervera, C.; Ysa, T. Key aspects of building retrofitting: Strategizing sustainable cities. J. Environ. Manag. 2019, 248, 109247. [CrossRef] [PubMed]

62. Carlucci, M.; Zambon, I.; Salvati, L. Diversification in urban functions as a measure of metropolitan complexity. Environ. Plan. B Urban Anal. City Sci. 2019, 47, 1289-1305. [CrossRef]

63. Zambon, I.; Serra, P.; Sauri, D.; Carlucci, M.; Salvati, L. Beyond the 'Mediterranean city': Socioeconomic disparities and urban sprawl in three Southern European cities. Geogr. Ann. Ser. B Hum. Geogr. 2017, 99, 319-337. [CrossRef]

64. Salvati, P.; Petrucci, O.; Rossi, M.; Bianchi, C.; Pasqua, A.A.; Guzzetti, F. Gender, age and circumstances analysis of flood and landslide fatalities in Italy. Sci. Total Environ. 2018, 610-611, 867-879. [CrossRef] [PubMed] 